\title{
Metals Leak from Tilled Soil in a Century-A Review
}

\author{
Gunnar Bengtsson $^{1}$ \\ ${ }^{1}$ Luruddsvägen 32, SE-17854 Ekerö, Sweden \\ Correspondence: Gunnar Bengtsson, Luruddsvägen 32, SE-17854 Ekerö, Sweden. Tel: 468-70-730-5482. E-mail: \\ gunnarbengt@telia.com
}

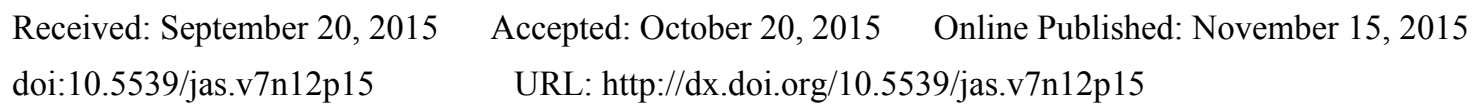

\begin{abstract}
Toxic metals are mobilized on a large scale in modern society. Many of those metals end up in sewage sludge. The objective of this review was to elucidate the threat to groundwater due to a few metals lost from tilled sludge amended soils. It is sometimes suggested that these metals are immobilized in the topsoil and do not move downward. In contrast, dozens of long term field studies around the world indicate that penetration depths for metals increase with time since deposition.
\end{abstract}

Such studies were examined in depth in the current analysis. An equation was developed for calculation of long term mean metal penetration rates into the topsoil for copper and silver. The equation is valid for about a century but not much longer. The mean depths of a basic set of 11 cases from studies over 4 years to 100 years were predicted with a standard deviation of $11 \%$. A typical penetration rate was $3 \mathrm{~mm}$ per year. There was no significant difference in penetration rate between several cations. Extremely large amendments were associated with larger penetration rates.

When metals have traversed the topsoil, the groundwater will be contaminated. The European Groundwater Pollution Directive stipulates that pesticide levels should be kept below $0.1 \mu \mathrm{g} / \mathrm{l}$. When sludge is applied to agricultural soil, this level may by far be exceeded for many metals, even if strict limitations are applied to the metal contents of the sludge. This calls for careful assessment of the groundwater consequences of sludge amendment.

Extensive supplementary material provides many detailed tables, texts and references.

Keywords: sludge, copper, silver, metal, organic carbon, amendment, leakage, mobility, topsoil, groundwater

\section{Introduction}

\subsection{Risks from Metals May Concern Human Health and the Environment}

Metals are a prerequisite for modern society and its agriculture, building, transportation and other endeavours. Mining for metals and other human activities mobilise more than 50000 million tonnes of materials per year (Organisation for Economic Co-operation and Development, 2008). For rare metals like osmium (Os) and iridium (Ir), anthropogenic mobilization may be more than a million times the natural mobilization from weathering, volcanic eruptions and the like (United Nations Environment Programme [UNEP], 2013). For more common metals like copper $(\mathrm{Cu})$, lead $(\mathrm{Pb})$ and tin $(\mathrm{Sn})$, anthropogenic mobilization may be more than ten times those of natural processes. The extracted metals in themselves may have very low toxicity, for instance steel and aluminium. Other metals, however, may be highly toxic, including contaminants of the masses of mobilized materials. For instance, natural sources account for emission of 7900 tonnes of arsenic (As) per year to the global atmosphere while anthropogenic sources are estimated to account for about three times that amount (International Agency for Research on Cancer, 2012). The arsenic sources include mining and smelting of base metals and coal burning.

The mobilized metals may cause exposures that are harmful to health, not the least for children. For instance, environmental levels of lead and mercury have been associated with effects on the central nervous system that may impact on intelligence or behaviour (Simeonov, Kochubovski, \& Simeonova, 2011). There is also a risk of effects on the environment. As an example relating to biological diversity, relatively large areas in Poland, Ukraine and Russia are at risk of losing 1 per cent of their environmental species due to contamination with cadmium and lead (UNEP, 2013). Heavy metals may also be significant contributors to poor status in rivers and 
lakes (European Environment Agency, 2015).

Some metals are used as plant protection products or biocides beause they are very harmful to environmental organisms. They are subject to particularly stringent assessment and licensing schemes by national or regional authorities. An important pathway for such metals to humans and the environment goes via wastewater and ensuing sewage sludge from wastewater treatment plants. This pathway is also relevant to other metals widely dispersed in the environment, for instance constituents in fuels, in paints and in vehicle components such as brakes, as well as food and feed additives; copper $(\mathrm{Cu})$ and zinc $(\mathrm{Zn})$ are often deliberately added to domestic animal feeds.

\subsection{Sewage Sludge Entails a Billion Dollar Businesss Inciting Sludge Amendment of Agricultural Soil}

In the rigorous assessments of biocides, risks from metals are particularly well addressed with respect to the wastewater pathways to human and environmental exposure. An important part of the assessment deals with the amendment of agricultural soil via deposition of sewage sludge on farmlands. The wastewater industry is a billion dollar business justified for many health and environmental reasons (Jardim et al., 2012). Cost efficiency incites recycling of nutrients in the produced sludge via amendment of land used for agriculture, forests and parks. About one-half of all sludge in Europe is used to amend agricultural land (Palfrey, 2011). This use is typically increasing, with Austria, Belgium, Denmark, Germany and Sweden as notable exceptions with diminishing use. Concern for health and environmental effects have lead to limitation of contaminants in the sludge used for amendment. In Europe, for instance, a sewage sludge directive from 1986 (86/278/EEC) sets metal limits for sludge and soil (cadmium, chromium, copper, lead, nickel, and mercury). In many countries there is a debate whether the amendment should be allowed and whether limits are stringent enough. Some countries, states or regions have prohibited such amendment.

\subsection{Many Metals Are Assumed to Remain in the Topsoil But Do They Instead Pass Through to Groundwater?}

Issues around metals from sludge amendent are thus economically and environmentally important and have a bearing on wider questions about the fate of metals in the environment. Decisions on potential restrictions should be informed by the best possible knowledge. But there is little quantitative information on metal transport through soil. A more detailed review is given in the Appendix and is summarised here.

$>$ Broader reviews of metals in the environment tend to pay much attention to metal chemistry and bioavailability but not to transport through soil. Overviews specialized on metals in soil enumerate factors that determine mobility and bioavailability in soil but do not give quantitative transport rates. Sometimes the focus is on soil chemistry and effects on soil related organisms

$>$ Some reviews discuss quantitative estimates of the transport of metals over very large land areas. However, they are based on rather limited empirical evidence of leaching through topsoil.

$>$ Some transport mechanisms have been reviewed in detail such as via colloids and via earthworms and other biological processes.

$>$ Organic matter is very important for the transport and has been reviewed in general or for specific metals such as copper. Again quantitative transport is not addressed.

$>$ A major review discusses risks of groundwater contamination but stays with relative risks of various contaminant, not quantitative leaching.

$>$ There is conflicting information as to whether metals are really transported through the topsoil. A perception of little loss from topsoil has lead to the assumption that metals are accumulated in soil over centuries without any significant loss. Protection of the soil organisms becomes the main purpose of restricting metal addition to soil. If instead many metals are transported through tilled soil in a time scale of a century, the medium to be protected may not be the soil but the groundwater, and a new paradigm for protection may need to be developed.

It is obvious from this brief review of existing research that metal penetration through soil is very complex and dependent on a multitude of chemical, biological and other factors. It is to be expected that any resolution to the conflicting findings needs to take a large number of issues into account and requires a relatively lengthy discussion.

\subsection{Objective: Test If Metals Are Transported through Topsoil in Decades and Find Implictions for Groundwater}

The purpose of the current review was to explore, using literature data, whether many metals move downward in agricultural soil in a timescale of a century, and if so elucidate the ramifications for groundwater protection. There is much information for copper and it was studied in the first hand, together with some information for its 
chemical analogue silver (Ag). Thereafter the behaviour of other metals in relation to copper was studied. The downward movement was illustrated using two parameters:

$>$ Mean penetration depth into the soil over the time period studied

$>$ Mean fractional loss from the agricultural topsoil.

Published articles from long term field studies were analyzed with respect to these parameters. In some cases, mechanistic experiences from laboratory studies were used to guide the analysis, but the priority was always the empirical evidence from field studies. Only average penetration rates were modelled, not the dynamic behavior that leads to these rates, nor the underlying depth distributions.

A brief review of the influence of agriculture on metal contents in groundwater was also intended.

\section{Method}

\subsection{Overview Concerning Metal Penetration in Topsoil}

The literature was searched for long term field studies giving depth profiles of metals in soil, and/or mass balance between supplied metals and metals in topsoil and subsoil. Criteria for eligibility as shown below were applied to selected studies of suitiable quality. Priority was initially given to copper $(\mathrm{Cu})$ which is datarich, and silver $(\mathrm{Ag})$ which is an analogue of copper. The reasons for using silver together with copper are given in the Appendix. Results obtained with copper $(\mathrm{Cu})$ and silver $(\mathrm{Ag})$ were later used for comparison with other metals. The mean penetration depths for copper and silver were calculated from the depth distributions in soil or losses from topsoil. All penetration depths were normalized to one soil bulk density $\left(1337 \mathrm{~kg} / \mathrm{m}^{3}\right)$. Mechanistic experiences and other findings from laboratory studies and review articles were used to guide hypotheses about the impact of different parameters enumerated below, such as $\mathrm{pH}$ and amount of precipitation. Default conditions for the parameters were defined, for instance $\mathrm{pH}=7$ and an annual precipitation of $700 \mathrm{~mm}$. Corrections to the field studies' penetration depths were applied to give corrected depths valid under the default conditions,. The mathematical form of these corrections was chosen so that the predicted penetration depths on average over many studies would equal the measured ones. In an iterative process, hypotheses resulting in large variations in the corrected penetration depth among the different studies were rejected. Hypotheses resulting in small variations were kept. The iteration was terminated when the variation could no longer be reduced without violating reasonable links to mechanistic experiences. The resultant weighting of the parameters involved was expressed in a penetration equation. Details about the parameters finally chosen are given in the Appendix.

\subsection{Criteria for Eligibility}

Data from a study would ideally be eligible for analysis if the following six conditions were met.

\subsubsection{Conditions Are Agricultural}

Conditions are similar to conditions commonly encountered in agriculture. This means i.a. that there will be organic life starting in the top soil with some vegetation cover, and continuing with a diversity of microorganisms and higher organisms deeper down. Further, soil conditions are paid particular attention in cases when the estimated mean penetration depth for the metal is beyond about $10 \mathrm{~cm}$; at larger penetrations the metal may enter soil layers with considerably reduced organic matter content and other conditions promoting rapid downward transport.

\subsubsection{Study Is Well Designed}

There are no ambiguities concerning the design of the study.

\subsubsection{Study Covers Many Years}

The initial metal was supplied to the surface of the soil at least 4 years ago.

\subsubsection{Data Can Be Accessed}

Data can be accessed on,

> Control soil levels of copper and other important metals in top soil;

$>$ Soil organic matter fraction;

$>$ Soil sand fraction;

> Mean depth to which metal is transported through tilling in a broad sense;

> Mean depth to which metal penetrates and/or supplied amounts of metals;

$>$ Levels of copper and other important metals; note that even when no supply of metal is intended, it might 
be supplied above all in manure and chemical fertilizer;

$>\mathrm{pH}$;

$>$ Exposure period;

$>$ Annual precipitation levels.

2.2.5 Parameters Have Little Variation with Time

The levels of organic matter and $\mathrm{pH}$ during the exposure period are not strongly variable.

\subsubsection{Metal Levels Are Clearly Enhanced}

The added level of metal in the topsoil is higher than the background level. The Appendix gives two examples built on amendment with pig slurry rich in organic matter. They illustrate that initial organic matter and metal may be lost from the topsoil. This may confound the loss of the added metal. To minimize such an effect, the amount of added metal should preferably be much higher than the amount already present in the soil.

In practice, all of this information was rarely available and judgment had to be exercised about reasonable compromises. Exceptionally, data outside of these selection criteria were used to elucidate the penetration in the soil. Elaborations on some of the criteria are given in the Appendix.

\subsection{Parameters of Interest and Assumptions Made}

Eleven parameters were examined. A number of assumptions were made that directed the present analysis of metal penetration into soil, in order to enable comparison between the results of different field studies. The following is a summary of most assumptions. Detailed motivations for some of the assumptions are given in the Appendix.

1) Precipitation controls the downward movement of metals in the soil. This means that one of the parameters should be the product of study time and annual precipitation. A power function describes the impact of this parameter on penetration. In addition, a century-long loss is described by a linear dependence. This assumption is based on century-long studies of organic matter loss in control soils (see Section 3.1 under Applicability beyond a century).

2) Organic matter and total metal are important. Following deposition, most metal is rapidly bound to organic matter. With time, the binding might change to less volatile forms. The total metal followed in field studies can be used to give sufficiently accurate predictions of penetration rates, and it is not necessary to employ the various fractions which have been extensively studied such as soluble or remaining metal.

3) Amount of organic amendment via e.g. manure or sludge may strongly influence the amount of organic matter in the topsoil and thus metal mobility.

4) Sand content is a sufficient soil structure parameter for describing the penetration rate into the soil, and the silt and clay levels are not needed for sufficient accuracy. The currently used definition of sand entails grain sizes between $0.074 \mathrm{~mm}$ and $2 \mathrm{~mm}$. When studies have used other definitions, the sand fraction has been recalculated to encompass this interval.

5) Mean time since deposition is assumed to be half of the total application time, unless detailed deposition data are available.

6) Displacement due to agricultural practices is small for no-till and mulch-till technologies. If there are indications of complete mixing, the average displacement of the surface applied metal is set to one half of the tilling depth.

7) $\mathrm{pH}$ influences the metal penetration depth according to a linear relationship. The background for this assumption is elaborated in the Appendix. $\mathrm{pH}$ (soil:water 1:1) has been used.

8) Depth distributions in soil are exponential if not measured with good spatial resolution. Then the penetration depth can be estimated from the fraction $\mathrm{L}$ of metal lost below depth $\mathrm{D}$ as $-\mathrm{D} / \ln (1-\mathrm{L})$. Actually, the distributions follow a much more complex pattern as illustrated for the metal cesium (Cs) in soil with extremely high organic matter content (the Hille case, Matisoff et al., 2011).

9) Bulk density is related to the soil content of organic matter according to independent literature data detailed in the Appendix. For the current analysis the data by Périé and Quimet (2007) are consistently used; they are based on a very large database and cover the required range of organic matter up to $10 \%$. The dry bulk density $\mathrm{B}$ $\left(\mathrm{g} / \mathrm{cm}^{3}\right)$ is related to soil organic matter o $(\mathrm{kg} / \mathrm{kg})$ by

$$
\mathrm{B}=-1.977+4.105 \times \mathrm{o}-1.229 \times \ln (\mathrm{o})-0.103 \times(\ln (\mathrm{o}))^{2}
$$


Depths of the original studies are recalculated to depths corresponding to bulk density $1337 \mathrm{~kg} / \mathrm{m}^{3}$, corresponding to the mass fraction 0.02 of organic matter. For instance, a depth of $20 \mathrm{~cm}$ at organic fraction 0.04 (bulk density $1076 \mathrm{~kg} / \mathrm{m}^{3}$ ) corresponds to $16.1 \mathrm{~cm}$ at $1337 \mathrm{~kg} / \mathrm{m}^{3}$. In other words, the depths were expressed in terms of mass per unit area.

10) Metal levels were initially hypothesized to influence penetration in soil. It turned out that this hypothesis need not be applied to get minimal variation in normalised penetration depths between different studies.

\subsection{Penetration of Other Metals than Copper and Silver}

The penetration of additional metals was studied by comparison with that for copper and silver. All of the available data were from metals that mainly have positive oxidation states. For these metals $\mathrm{M}$, the penetration depths from the penetration equation were augmented by a multiplier to allow comparison with copper/silver penetration in one of two ways:

$>$ If data for silver/copper were available in the same study, the ratio of penetration depths was calculated. The copper penetration was assumed to follow the penetration equation and the ratio was defined as the multiplier. In this way many uncertainties were eliminated, e.g. pertaining to soil depth and organic matter fraction.

$>$ If no data for copper/silver were available, the penetration equation was modified with a multiplier to make the calculated penetration depth match the measured one.

In most cases the multiplier was derived from comparison of the losses $\mathrm{L}$ from topsoil depth $\mathrm{D}$ undergone by the metal in question, $\mathrm{M}$, and copper, $\mathrm{Cu}$. In cases where the metals were surface deposited, the multiplier was assumed to be $\ln \left(1-\mathrm{L}_{\mathrm{M}}\right) / \ln \left(1-\mathrm{L}_{\mathrm{Cu}}\right)$. Where the metals had been incorporated by mixing to depth $\mathrm{D}$, the mean penetration depths $\mathrm{d}$ were solved from the following expression using the Microsoft Excel Problem Solver:

$$
\mathrm{d}=\mathrm{D} / \ln (1-\mathrm{D} \times \mathrm{L} / \mathrm{d})
$$

On the whole, cases were selected with parameters inside the ranges for which the penetration equation was derived (see Section 3.1). Several studies were deselected since they encompassed many metals but the time distribution of the metal supply was unknown.

\subsection{Penetration of Metals in Control Soils}

In some studies it was possible to derive the losses of metals from control topsoil over a number of years. The loss was corrected to pertain to a default soil bulk density $\left(1337 \mathrm{~kg} / \mathrm{m}^{3}\right)$. The previous treatments of the control soils were unknown and often the metal content of any used fertilizer was not given, so the results should be viewed with caution. From the loss rate, a penetration rate was derived using equation 2 . Because of the low metal levels, the results were uncertain and sometimes control levels even increased with time. Even such increases were included when average penetration rates were calculated, since they might have counterparts with unduly large losses.

\subsection{Penetration of Metals Following Unusually Large Amendments}

The organic matter in topsoil may often be changed by up to $10 \mathrm{Mg} /$ hectare per year. If the change is larger, it can be expected to significantly influence the metal penetration. Studies involving similar or larger organic matter amendments were treated separately from studies with lower amendments, and were not used to derive the penetration equation. The metal penetrations from studies with large amendment were estimated. The penetration depths from the penetration equation were augmented by a multiplier to give a calculated depth equal to the one estimated from the field studies. The multiplier was examined as a function of the magnitude of the amendment.

\subsection{Penetration of Metals Following Increases in Soil Organic Matter}

Organic matter in topsoil is known to be partitioned to compartments of different residence time, from labile organic matter residing about a year to intermediate staying a decade and passive remaining for centuries or more (Food and Agriculture Organization, 2004). Metals being bound to organic matter should follow the interchanges between these compartments. This suggests the hypothesis that the change in organic matter in topsoil is an interesting determinant for metal penetration. An additional hypothesis is that added organic matter that is used to build up soil organic matter is not available for loss at all. The hypotheses were examined using data from Andersson 2012. In these field studies, copper retention was studied over three decades for one soil that had little change in organic matter, and one that had a high degree of change, while many other parameters were the same. The relative loss of copper from topsoil for these two sites was examined as a function of the change of soil organic matter. 


\subsection{Penetration of Metals below the Topsoil and Losses to Sinks}

Some metal reaches the subsoil. Here further penetration may proceed relatively rapidly, promoted for instance by preferential pathways. The retention was studied for cases where metals had been measured at depths between 1 and 2 meters. The mass of metal retained at these depths relative to that in the topsoil was calculated.

In some cases the metals may be captured in sinks and further transport may be delayed. No quantitative estimates were made for losses to sinks, but some literature was analysed as part of the discussion of the penetration results.

\subsection{Metal Loss to Groundwater and Its Significance}

A basic hypothesis was that metals are lost from the topsoil in a century or so, dependent on a large number of parameters. If metals were supplied to the topsoil at a constant rate, this would in the long term lead to an equilibrium between supplied and lost metal, in the unlikely event that all other parameters were unchanged. The metal concentration in the percolation water would then depend only on the amount of percolated water. For calculations, an average annual precipitation of $700 \mathrm{~mm}$, and groundwater formation of $370 \mathrm{~mm}$ have been used. For the metal supply, permissible levels in applied sludge have been established by several countries and also at the regional European level. These regulations however comprise only a few metals. Permissible levels for supply of a larger set of metals have been established in Sweden (Svenskt Vatten, 2015) and these have been used to illustrate the significance of groundwater contamination.

\section{Results and Discussion}

\subsection{Penetration of Copper and Silver in Topsoil and the Penetration Equation}

In section 2, criteria for eligibility of field studies, and assumptions governing the analysis were given. These were used to select for final analysis 11 cases deriving from 8 studies referenced in the Appendix. With one exception, the soil management procedures involved little downward displacement of the metals. The exception was Lorenzoni et al. (2007), where harrowing was assumed to have displaced the metals on average $2.5 \mathrm{~cm}$ downwards. In all cases, the mean amount of amendment per single occasion was less than $10 \mathrm{Mg} / \mathrm{hectare}$; note that He, Endale, Schomberg, and Jenkins (2009) and Tiecher et al. (2013) used a total amendment over a number of years of about $80 \mathrm{Mg} /$ hectare. Correction has been made to a soil bulk density of $1337 \mathrm{~kg} / \mathrm{m}^{3}$. The mean penetration was in 6 cases derived using the fractional retention in the top $5 \mathrm{~cm}$ of soil, and in 5 cases that in the top $20 \mathrm{~cm}$. Using successive approximations, the following penetration equation was derived.

$$
\mathrm{d}=\mathrm{d}_{\mathrm{t}}+1.9 \times(-0.064 \times \mathrm{pH}+0.73) \times \mathrm{s}^{0.43} \times(1-\mathrm{s}+\mathrm{o})^{0.5} \times(\mathrm{p} \times \mathrm{t})^{0.3} \times(1+0.006 \times \mathrm{p} \times \mathrm{t}) / \mathrm{o}^{0.5}
$$

The symbols have the following meaning (in parentheses are given the ranges of the data used in derivation of the penetration equation):

$\mathrm{d}_{\mathrm{t}}$ : Downward displacement of the metals due to soil management procedures, $\mathrm{cm}(0-2.5)$;

o: Organic matter fraction in the soil (0.01-0.11);

s: Sand fraction (0.27-0.89);

$\mathrm{pH}$ : Soil pH (4.5-6.5);

p: Precipitation rate, mm/year (700-1793) normalised to typical precipitation by division by 700 ;

t: Mean time since deposition, years (4-50).

The reasons behind the choice of mathematical functions (linear and power functions) are explained in the Appendix. The numerical values in the equation were those that on average over all cases resulted in predicted mean penetration depths equaling the measured ones. At the same time they gave the smallest variation of measured vs predicted values, with a relative standard deviation of $11 \%$. The numbers have been rounded to one or two significant figures. Details are given in Table 1. It should be noted that many other combinations of numerical values will give nearly the same mean penetration depths and the same variation in predictive capability.

The penetration equation should be valid within the range of parameters for which it was derived, subject to the restrictions and assumptions given in Sections 2.2 and 2.3. In particular, the decreased penetration depth at large fractions of soil organic matter (above about 0.2) invalidates the equation. An extreme case in point is copper bound in isolated (ombrotrophic) peat, where the copper can be bound for millennia (Mighall et al., 2009) and thus be completely immobile.

Further, it should be noted that temperature is a very important parameter for transformation of organic matter in 
soil (Conant et al., 2011); for instance freeze-thaw cycles may lead to rupturing of walls and membranes in living cells and ensuing release of organic matter. The mean annual temperature at the experimental sites was not included as a separate parameter, and the penetration equation should be applied with caution at temperatures outside the approximate interval $10^{\circ} \mathrm{C}-18^{\circ} \mathrm{C}$.

Applicability to times beyond a century is discussed below. Relevance for other metals than copper and silver is discussed in subsection 3.2. Further discussion is also given in subsections 3.3-3.6.

Table 1. Cases eligible for the derivation of the penetration equation and their parameter values

\begin{tabular}{|c|c|c|c|c|c|c|c|c|c|c|c|c|}
\hline \multirow{2}{*}{ 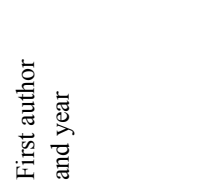 } & \multirow[b]{2}{*}{ 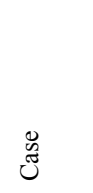 } & \multirow{2}{*}{$\begin{array}{l}0 \\
\stackrel{2}{I} \\
\underline{I} \\
\underline{2}\end{array}$} & \multirow{2}{*}{ 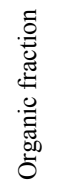 } & \multirow{2}{*}{ 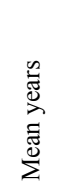 } & \multirow{2}{*}{ 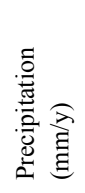 } & \multirow{2}{*}{ 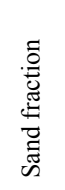 } & \multirow{2}{*}{ 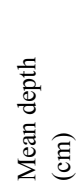 } & \multicolumn{2}{|c|}{$\begin{array}{l}\text { Fraction of metal } \\
\text { lost below }\end{array}$} & \multirow{2}{*}{ 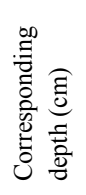 } & \multirow{2}{*}{ 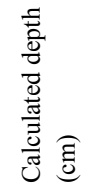 } & \multirow{2}{*}{ 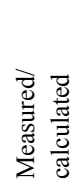 } \\
\hline & & & & & & & & $5 \mathrm{~cm}$ & $20 \mathrm{~cm}$ & & & \\
\hline Handl 2000 & $4.75 \mathrm{y}$ & 5,3 & 0,114 & 4,8 & 700 & 0,75 & 1,9 & 0,0602 & & 1,78 & 1,9 & 0,923 \\
\hline Tiecher 2013 & DL90 & 6,3 & 0,048 & 4,1 & 1471 & 0,59 & 2,9 & 0,201 & & 3,12 & 3,1 & 1,013 \\
\hline He 2009 & NT & 6,4 & 0,021 & 4,4 & 1250 & 0,75 & 5,2 & 0,275 & & 3,87 & 3,8 & 1,023 \\
\hline Miotto 2012 & 2 & 5,8 & 0,010 & 4,6 & 1388 & 0,88 & 5,4 & 0,321 & & 4,40 & 4,8 & 0,924 \\
\hline Casali 2008 & Humic & 6,2 & 0,040 & 20,0 & 1793 & 0,36 & 9,1 & & 0,051 & 6,72 & 7,2 & 0,938 \\
\hline Mantovani 2009 & Lito & 6,5 & 0,027 & 23,5 & 1650 & 0,57 & 5,7 & 0,500 & & 7,21 & 8,6 & 0,839 \\
\hline Miotto 2012 & 3 & 6,1 & 0,011 & 17,6 & 1388 & 0,89 & 7,7 & 0,546 & & 8,26 & 7,2 & 1,142 \\
\hline Casali 2008 & Lito & 6,2 & 0,040 & 20,0 & 1793 & 0,35 & 10,1 & & 0,091 & 8,34 & 7,1 & 1,170 \\
\hline Mirlean 2007 & P61 & 4,5 & 0,023 & 30,5 & 1400 & 0,35 & 14,0 & & 0,174 & 11,44 & 13,6 & 0,840 \\
\hline Lorenzoni $2007 *$ & 13 & 5,9 & 0,011 & 20,0 & 748 & 0,47 & 16,7 & & 0,263 & 13,10 & 12,2 & 1,076 \\
\hline Mirlean 2007 & P100 & 4,7 & 0,026 & 50,0 & 1400 & 0,27 & 18,2 & & 0,320 & 17,55 & 16,0 & 1,097 \\
\hline Average & & & & & & & & & & & & 0,999 \\
\hline Standard deviation & & & & & & & & & & & & 0,1149 \\
\hline
\end{tabular}

Note. *Tilling correction $2.5 \mathrm{~cm}$.

\subsubsection{Applicability beyond a Century}

A major uncertainty pertains to time spans above a century or so, for which there are little experimental data upon which the measured penetration depth can be based. Three arguments support the contention that the penetration equation may not be grossly in error at times upwards of two centuries, albeit further research is necessary for a confirmation:

1) Organic matter is continually lost from unamended but tilled soils. The organic matter loss was still ongoing after 80 years (Barré et al., 2011), although at a slightly reduced rate consistent with an approach to an equilibrium level that was higher in clayey soils than in sandy soils. The mean fractional loss was around 0.01 per year with $700 \mathrm{~mm}$ precipitation (derived from Barré et al., 2011), corresponding to a mean downward movement of $0.29 \mathrm{~cm} /$ year $(95 \%$ confidence interval $0.19-0.39 \mathrm{~cm})$. This is near the average movement that was observed for copper and zinc in control soils of $0.38 \mathrm{~cm} /$ year (0.24-0.52), (see Section 3.3), and for copper and silver in the studies used to define the penetration equation, $0.32 \mathrm{~cm} /$ year $(0.20-0.45)$. There is a strong correlation between organic matter and the contents of several metals. Therefore, the agreement in penetration rates for the long term organic matter, the metals in control soils, and the metals according to the penetration equation, may be more than fortuitous.

2) A regional model for metal transport (Römkens, Bonten, \& Rietra, 2004) contains essentially the parameters of the penetration equation in a similar structure of power functions (and additionally the concentrations of dissolved organic carbon and of oxalate extractable iron and aluminium). There is reasonable consistency between results of that model and various long term measured data (Groenenberg et al., 2006). The model is 
based on dissolved metal in the soil being transported with percolation water, corresponding to a purely linear time dependence in the penetration equation.

3) Groenenberg, Römkens and de Fries (2006) also refer to the long term agricultural experiments at Hoosfield and Broadbalk for which the copper levels in soil showed equilibrium after 120-150 years of study. Results of those experiments can be compared with results derived from application of the penetration equation, using correction for the large amendments of farmyard manure as described in subsection 3.4. The comparison cannot demonstrate any inconsistency in two respects:

a. The time span to reach equilibrium.

b. The level of copper in soil at equilibrium.

The uncertainties are large, however, because of i.a. the spatial variations in $\mathrm{pH}$ and sand contents at Hoosfield and Broadbalk, and the lack of knowledge of the copper content of the applied manure. For instance, the difference of net copper levels of a factor of two between Hoosfield and Broadbalk cannot be explained unless extreme values of sand and $\mathrm{pH}$ levels within their measured ranges are assumed.

\subsubsection{Predicted Losses from Topsoil}

Figure 1 gives the expected losses of metals from a tilled $15 \mathrm{~cm}$ topsoil layer as a function of accumulated precipitation for three model cases with very different parameter sets (Table 2). The metal has been assumed to be supplied once at time zero.

Table 2. Numerical values for calculated examples of loss from $15 \mathrm{~cm}$ topsoil

\begin{tabular}{llll}
\hline Parameter & Middle & High & Low \\
\hline $\mathrm{pH}$ & 7 & 4 & 7 \\
Organic matter fraction & 0.02 & 0.005 & 0.1 \\
Tilling correction, cm & 0 & 0 & 0 \\
Sand fraction & 0.7 & 0.52 & 0.1 \\
Soil bulk density, $\mathrm{kg} / \mathrm{m}^{3}$ & 1337 & 1663 & 717 \\
\hline
\end{tabular}

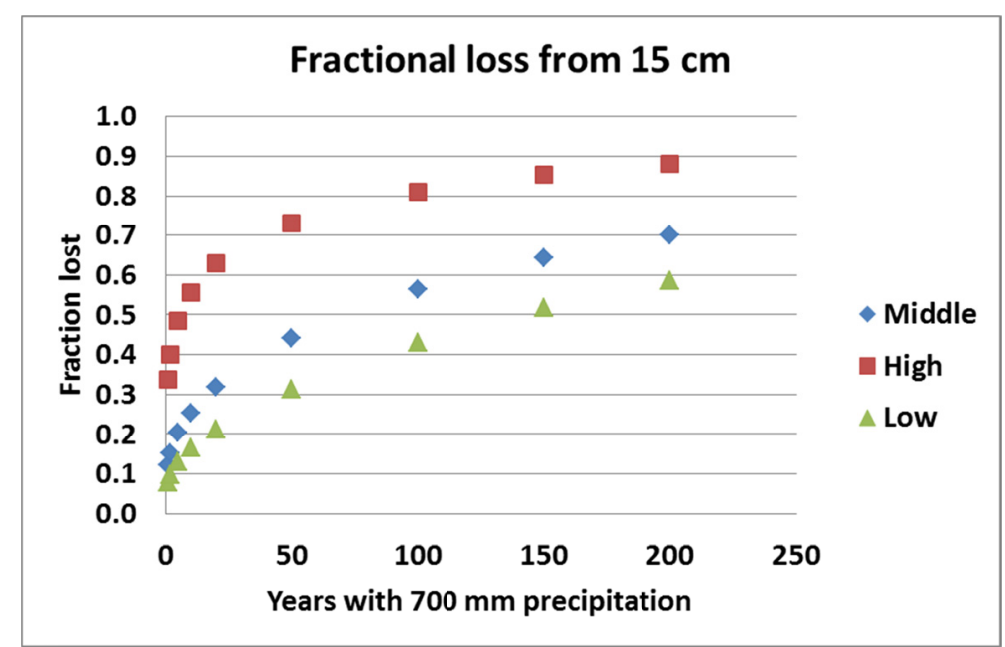

Figure 1. Examples of losses of metals from $15 \mathrm{~cm}$ tilled topsoil derived from the penetration equation, for different combinations of parameters

Note. Three model sets of parameters with different mean penetrations are used for illustration. The sets have numerical values as given in Table 2. The mean penetration depths for metals in soil in the examples range from about $1 \mathrm{~cm}$ to beyond the $15 \mathrm{~cm}$ topsoil depth. Note the limitations discussed in Section 3.1 with respect to the ranges of validity of the parameters. In particular, at times beyond a century there is little empirical basis for the curves. 


\subsection{Penetration of Other Metals than Copper and Silver}

In column experiments, there are often large differences in penetration between different metals. For instance, in one experiment, nickel $(\mathrm{Ni})$ leached more than copper $(\mathrm{Cu})$ while zinc $(\mathrm{Zn})$ was absorbed in the solid phase (Ashworth \& Alloway, 1994), while in another, zinc and cadmium (Cd) leached significantly while lead $(\mathrm{Pb}) \mathrm{wa}$ immobilized (Li \& Shuman, 1997). In contrast, under more fieldlike conditions, there have been several observations that differences in topsoil penetration between metals are small, tentatively explained by for instance preferential flow in cracks and macropores (Camobreco, Richards, Steenhuis, Peverly, \& McBride, 1996), and bioturbation by earthworms (Radesh, Reddy, Naidu, \& Ramavataram, 2003; Fernandez, Labanowski, Cambier, Jongmans \& Van Oort, 2007; Jarvis, Taylor, Larsbo, Etana, \& Rosén, 2010). Several other mechanisms controlling metal transport are given in the Appendix. Cesium had similar mobility in soil and sediment as silver despite the very different chemistry of these metals (Lepage et al., 2014). To test similarities and differences in penetration between different metals, long term field studies involving 8 metals besides copper and silver were analysed. The null hypothesis was that the other metals had the same penetration rate as copper and silver. The transport of cadmium $(\mathrm{Cd})$, cesium $(\mathrm{Cs})$, chromium $(\mathrm{Cr})$, lead $(\mathrm{Pb})$, manganese $(\mathrm{Mn})$, molybdenum $(\mathrm{Mo})$, nickel $(\mathrm{Ni})$, and zinc $(\mathrm{Zn})$ was analyzed for 9 long term field studies comprising 17 cases. The penetration data are detailed in the Appendix. The penetration rates in the topsoil of the other metals were compared to those of copper and silver and described via a multiplier to the penetration equation. For a total of 41 cases with different metals, the mean penetration depth was on average the same as that of copper, with an overall $95 \%$ conficence interval of 0.92-1.08 (Figure 2). The null hypothesis could not be rejected on the basis of the results. This means that the penetration rate is consistent with the predicted penetration rates of copper and silver upon which the penetration equation is based. For individual metals, penetration rates differing by several times ten per cent cannot be ruled out. The basic data represent quite different conditions, for instance $1-17$ years of study and depths of $2-50 \mathrm{~cm}$. However, only some 30 different soils were represented and there may be soil types for which the difference between metals is larger.

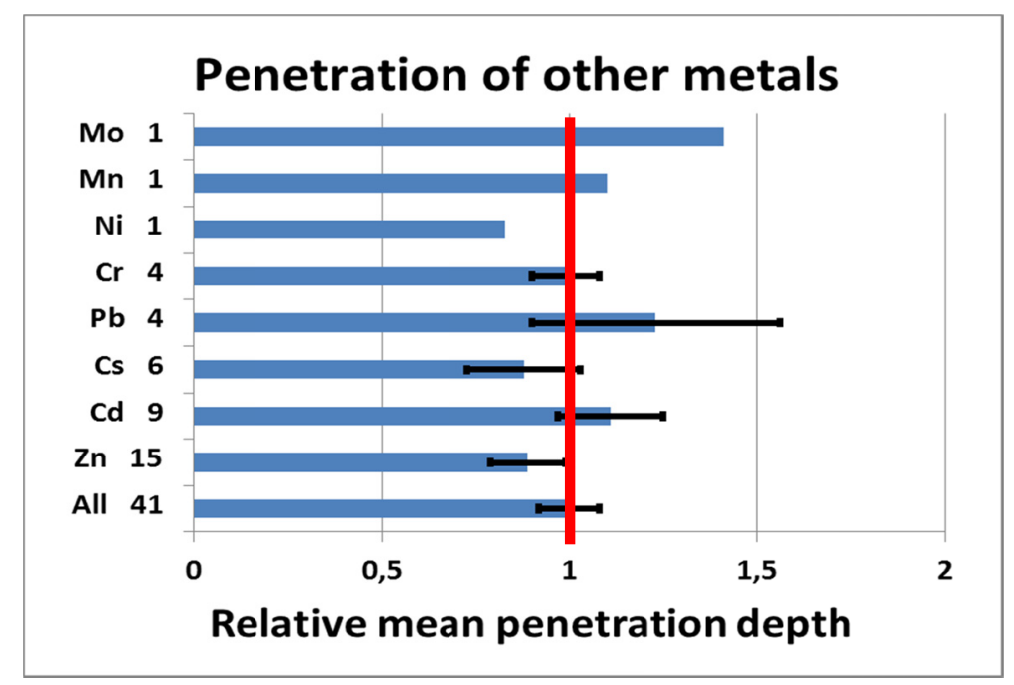

Figure 2. Average measured relative penetration depths for other metals than copper or silver

Note. Mean penetration depths were measured in long term field studies and compared to those measured for copper in the same study; in the case of cesium the comparison was made with the penetration equation. The relative penetration depth is expressed as a multiplier to the penetration equation. The vertical axis gives the symbols of the elements and the number of cases upon which the average measured depth is based. The bars give $95 \%$ confidence intervals. The deviations from unity (at the fat red line) are not statistically significant at the $95 \%$ confidence level. A detailed table is given in the Appendix.

A few pieces of evidence from non-eligible studies are in line with the penetration equation.

$>$ Labanowski et al. (2008) studied fallout from a nearby smelter accumulated over almost a century. The mean penetration depth for cadmium, zinc and lead was 0.8 of the one calculated using the penetration equation. Uncertainties concern i.a. the time pattern of metal deposition. 
Depage et al. (2014) measured the depth distribution of silver and cesium a year after the Fukukshima accident. The mean penetration depth was 0.7 of the one calculated using the penetration equation. Uncertainties concern i.a. the extremely low bulk density and the high organic matter content of the soil.

\subsection{Penetration of Metals in Control Soils}

Control soils also lose metals in the long run, if left unamended. Because control soils in general have low metal levels, changes in these levels tend to have large relative variations. Ten cases of long term field studies involving zinc and twelve involving copper met the selection criteria. In summary, zinc in control soils was lost over time at approximately the same rate as copper. The rate is not inconsistent with that derived from the penetration equation, within very large limits of error. Some details are given in the Appendix.

\subsection{Penetration of Metals Following Unusually Large Amendments}

The penetration into topsoil was separately calculated for total amendments much higher than $10 \mathrm{Mg} / \mathrm{ha}$. A total of 12 cases met the selection criteria, deriving from 8 publications. Further, 7 cases from Brown, Chaney, and Angle (1997) were analyzed. In the latter cases, some information was missing and assumptions had to be made about sand and organic contents of the soil. The cases included single surface deposition (1 case), single tilled amendment (12), and multiple tilled amendments (6). The penetration rates were described via a multiplier to the penetration equation. On the whole, the penetration rate increased linearly with the total amount of amendment, with rather large variations (Figure 3). The multiplier increases approximately with 1 unit per $200 \mathrm{Mg} / \mathrm{ha}$ of amendment, to reach a maximum of about 5 at $800 \mathrm{Mg} /$ hectare. At such an amendment, the typical penetration rate is about $5 \times 0.3 \mathrm{~cm} /$ year, or $150 \mathrm{~cm}$ in a century. Within the uncertainty, there is room for a threshold of about $50 \mathrm{Mg} / \mathrm{ha}$ below which the multiplier is 1 . There is also a possibility that at large amendments, the multiplier may approach equilibrium in the case of multiple as opposed to single amendments. At present this is only hypothetical in view of the large uncertainties. Details are given in the Appendix.

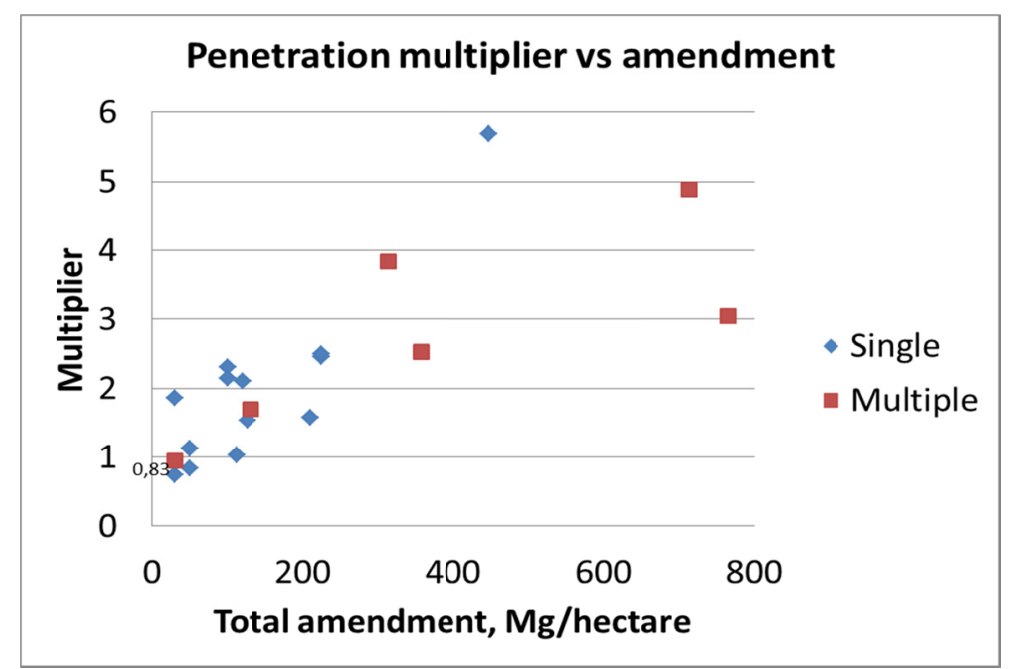

Figure 3. Dependence of the penetration rate on the total amendment with sewage sludge

Note. The rate of penetration into soil is given by a multiplier to the penetration equation. The rhombs pertain to cases with one initial amendment; the squares pertain to multiple amendments.

\subsection{Penetration of Metals Following Increases in Soil Organic Matter}

In a field study of sludge amendment over three decades (Andersson, 2012), one soil (Igelösa) exhibited almost a doubling of the organic matter the first 15 years, while the other (Petersborg) had essentially constant organic matter content. This was concomitant with about half the rate of loss of copper from the topsoil at Igelösa relative to that of Petersborg. A potential explanation might be that the metal is more strongly retained if the organic matter increases. There are a few cases that hint towards significantly reduced penetration when the organic matter levels have increased after a first amendment year. Because of several uncertainties, the explanation remains a hypothesis that requires testing against other data. Details are given in the Appendix. 


\subsection{Penetration of Metals below the Topsoil and Losses to Sinks}

Is the rate of loss of copper from the topsoil a good approximation to the total rate of loss to groundwater including deeper subsoil layers? This would depend on potential accumulation on the way to the groundwater. Two modes of accumulation were analysed: fixation in the subsoil and losses to sinks for metals. Details are given in the Appendix.

$>$ Accumulation in the subsoil at 1 to 2 meters depth seems rather uncommon. Out of 13 cases reporting measurements at these depths, only one suggested any strong accumulation, associated with a local change in soil parameters. Details are given in the Appendix. On the whole, even for century-old contamination, metal concentrations decreased with depth.

$>$ Even though many metals largely find their way through the subsoil to groundwater, there are examples when the metals may be trapped for long times in sinks. The dominant example refers to peat or peaty soils. Some engineered sinks may also delay the transport of metals but evidence beyond a couple of decades is scanty. Over a century or more, it is hard to justify any major general reduction of environmental concentrations due to metals being trapped in sinks, except for the trapping in peat.

\subsection{Metal Loss to Groundwater and Its Significance}

Sludge and manure are very broadly applied as fertilizers in agriculture. Their long term application to agricultural soil combined with disregard for leakage though the soils could lead to high groundwater levels of metals. If there is little retention in the soil, near equilibrium will be established over decades, or in some cases centuries. Then an amount equivalent to the supplied amount is transferred to the groundwater, with little loss but with a delay of decades or centuries. Indeed, there is already a widespread contamination of groundwater by some metals in agricultural areas. Drainage water from Swedish farm fields contained levels of copper, zinc and cadmium that were 10-35 times those of natural waters (Ejhed et al., 2005). Table 3 shows the expected groundwater levels from sludge amended farm fields after equilibrium between supply to the fields and leakage, in the absence of significant sinks. The metal contents in the sludge are the maximum ones tolerated under the very strict Swedish quality system for sludge, REVAQ (Svenskt Vatten, 2015).

Table 3. Theoretically calculated long term metal levels in newly formed groundwater under sludge amended farm fields

\begin{tabular}{lllllllll}
\hline & $\mathrm{Cu}$ & $\mathrm{Zn}$ & $\mathrm{Cd}$ & $\mathrm{Pb}$ & $\mathrm{Cr}$ & $\mathrm{Ni}$ & $\mathrm{As}$ & $\mathrm{Ag}$ \\
\hline Natural level in groundwater, median $\mu \mathrm{g} / \mathrm{l}$ & 0.88 & 4.30 & 0.012 & 0.030 & 0.19 & 0.38 & 0.12 & 0.006 \\
$\begin{array}{l}\text { Intended permissible level in sludge in 2026 according } \\
\text { to REVAQ, g/ha, year }\end{array}$ & 300 & 600 & 0.37 & 25 & 40 & 25 & 22 & 0.56 \\
$\begin{array}{l}\text { Level in new groundwater at permissible sludge level, } \mu \mathrm{g} / 1 \\
\text { Level in new groundwater relative to natural level }\end{array}$ & 81 & 162 & 0.10 & 6.8 & 11 & 7 & 6 & 0.15 \\
\hline
\end{tabular}

Note. The source term is metal levels in sludge according to the long term intentions of the Swedish quality system for sludge, REVAQ. The requirements purport to cause no more than doubling of natural soil metal levels in 500 years, although regulatory levels for zinc, copper, cadmium and nickel have replaced the intended levels (Svenskt Vatten, 2015). Groundwater formation is assumed to be $370 \mathrm{~mm} /$ year. No retention in the soil is assumed. Natural water levels are from Sveriges Geologiska Undersökning (2013) except for silver where a median is used of data from Peters, Simpson, Merrington, Rothenbacher, and Sturdy $(2011 ; 0.006 \mu \mathrm{g} / \mathrm{l})$, Goodyear (2011; around $0.005 \mu \mathrm{g} / \mathrm{l})$ and Svensson et al. (2013; 0.005-0.01 $\mu \mathrm{g} / \mathrm{l})$.

After decades or centuries, a very high enhancement to $8-225$ times the natural levels could thus be expected right under the agricultural fields. As the percolation water is transported further away, there will in practice be dilution and attenuation. There is a risk of significantly enhanced natural metal levels even after dilution and attenuation in intensely agricultural areas, where farm fields occupy a large share of all land, or in areas where sludge is extensively applied to farmlands.

\subsubsection{Protection against Enhanced Levels of naturally Occurring Substances}

Many metals are present in the environment and have been used by mankind for millennia. Policymakers struggle with regulating levels of such metals while avoiding regulating the natural levels that are already there. 
EU guidance on metal risk assessment (European Chemicals Agency [ECHA], 2008) discusses the added risk approach. In essence this approach assumes that species are fully adapted to the natural background concentration and therefore only the anthropogenic added fraction should be regulated or controlled. In case it can be expected that the background is significant in comparison with the predicted no effect concentration, the added risk approach may be employed as a pragmatic solution.

Background levels usually have a broad distribution around a mean. The mentioned recommendation (ECHA, 2008) does not give a clear guidance on the point of departure within this distribution. Some examples of interpretations with respect to the distribution are given in the Appendix. The decision makers in these cases thus recognized that several times higher levels than the typical or median background levels are tolerable. Indeed, the 90th percentile of the Table 3 metal concentration in European water is 2.4- 5.3 times the median according to Salminen (2015); no water data were available for silver. The ultimate row of Table 3 suggests that even the 90th percentile is exceeded after long-term equilibrium for all of the metals.

\subsubsection{A Tiered EU Approach towards Tolerable Metal Levels in Water}

Protection of groundwater and other freshwater is subject to complex regulation in the European Union, embodied in several regulations and directives. A tiered approach is used, starting with comparison with certain nominal tolerable levels. If there is not compliance with these, other tiers are employed, ending with a full-fledged assessment at the local scale taking into account potential environmental and health effects.

1) Many metals have been used as biocides which are part of the concept of pesticides dealt with in the European Union Groundwater Directive (2006). The Directive stipulates that good chemical status prevails if the average annual groundwater level is below 0.1 microgram per liter. The mentioned groundwater levels due to sludge amendment (Table 4, penultimate row) are in conflict with this requirement for all of the metals addressed.

2) The European Union Water Framework Directive (2000) requires all groundwater to have "good chemical status". This has entailed implementing regulations in member states defining environmental quality standards, only to be exceeded if it can be shown that associated environmental risks are not significant. At the EU level, environmental quality standards have been set for surface water (not groundwater) for the priority metals cadmium, lead and nickel. These are at concentrations that are 8-80 times those of the median Swedish water (Sveriges Geologiska Undersökning, 2013). The mentioned groundwater levels due to sludge amendment (Table 4, penultimate row) are essentially in compliance with the standards, being near the standards for cadmium and lead and clearly below for nickel.

3) At even higher metal levels, the European Union Groundwater Directive (2006) permits exceedance of the pesticide or threshold values if a detailed assessment shows that the concentrations of pollutants are not considered to present a significant environmental risk. Member states should assess the health and environmental risks from these pollutants where large amounts of drinking water may be extracted, according to the European Union Water Framework Directive (2000).

The long term actual levels in groundwater due to sludge amendment seem to be broadly compliant with EU legislation, judging from the examples given above. For several metals they are clearly out of compliance with the Groundwater Pollution Directive stipulation that pesticide levels should be kept below $0.1 \mu \mathrm{g} / \mathrm{l}$. Because of this, a thorough assessment of the impact on groundwater of sludge amendment practices seems warranted.

\section{Conclusions}

The large-scale mobilization of toxic metals in modern society raises questions about associated health and environmental effects. Many metals are ending up in sewage sludge. The current paper shows that metals from sludge amended agricultural soils have penetrated the topsoils to a large extent, according to many long term field experiments. For time periods up to several decades, the penetration follows a penetration equation based on soil $\mathrm{pH}$, organic and sand content, time and annual precipitation. If a number of eligibility criteria are met, the equation describes the penetration depth quite accurately, with a standard deviation of the order of ten per cent. In typical tilled topsoil, most of the metal will be lost within a century. Slower loss will occur at high $\mathrm{pH}$, high organic fraction and very low or very high sand contents. Similar rates of loss occur in control soils without any amendment.

There are many indications that the penetration in topsoil is mediated by organic matter and is not primarily due to movement of simpler compounds of the metal. In the time perspective of decades, there are relatively small differences in the penetration of silver, copper, cadmium, chromium, zinc, nickel, lead, manganese, molybdenum and cesium.

The penetration rate is enhanced at large amounts of amended organic matter, with the rate at small amounts 
increasing by approximately one unit for every $200 \mathrm{Mg} / \mathrm{ha}$ of total amendment.

Some long term field studies have analysed metal contents at depths of one to two meters. Even for century-old contamination, metal concentrations generally decreased with depth. This is consistent with studies that indicate few major sinks for metals beyond the powerful sinks provided by peat or peaty soils. Thus, a large part of the metal can be expected to make its way through to the groundwater. With current practices, sludge amendment might lead to metal levels up to 200 times the natural levels in groundwater immediately beneath sludge amended agricultural soils. While this is violating default rules for pesticide contamination in the Europan Union, it might be permissible according to higher tiers of groundwater protection. More elaborate analyses of the tolerability of sludge amendment practices thus seem warranted to ensure groundwaters are adequately protected.

Further research is needed to clarify important questions:

$>$ Does the rate of loss decrease in cases when the soil organic matter is increasing over the years?

$>$ Do extremely large single organic amendments increase the rate of penetration more than the corresponding multiple amendments?

$>$ Is it common that metals are trapped in the subsoil for centuries?

\section{Acknowledgements}

The author is indebted to Per-Göran Andersson for suggestions and unpublished information relating to the unique Swedish long term study (Skåneförsöken) that prompted the author's interest in the issue of metal penetration in soil. He also wishes to acknowledge essential unpublished information provided by Kwon-Rae Kim concerning the long-term assessment of the environmental fate of heavy metals in agricultural soil made in the Republic of Korea, and by Hugo Lepage on metal penetration in soil after the Fukushima accident.

\section{References}

[Other additional references are quoted and listed in the Appendix.]

Andersson, P. G. (2012). Sludge amendment of agricultural soil (In Swedish: Slamspridning på åkermark). Hushållningssällskapens rapportserie 16 [This report also gives references to the earlier series of publications on the same field study, the data of which have also been used]. Borgeby, Sweden: Hushållningsällskapet Skåne. Retrieved from http://hushallningssallskapet.se/?projekten=slamspridning-pa -akermark

Ashworth, D. J., \& Alloway, B. J. (1994). Soil mobility of sewage sludge-derived dissolved organic matter, $\begin{array}{llllll}\text { copper, nickel and zinc. Environmental Pollution, 127, } & \text { 1374. }\end{array}$ http://dx.org.doi/10.1016/S0269-7491(03)00237-9

Barré, P., Eglin, T., Christensen, B. T., Ciais, P., Houot, S., Kätterer, T., ... Chenu, C. (2010). Quantifying and isolating stable soil organic carbon using long-term bare fallow experiments. Biogeosciences, European Geosciences Union (EGU), 2010, 3839-3850. http://dx.doi.org/10.5194/bg-7-3839-2010

Brown, S., Chaney, R., \& Angle, J. S. (1997). Subsurface liming and metal movement in soils amended with lime-stabilized biosolids. Journal of Environmental Quality, 26, 724-732. http://dx.doi.org/10.2134/jeq1997.00472425002600030018x

Camobreco, V. J., Richards, B. K., Steenhuis, T. S., Peverly, J. H., \& McBride, M. B. (1996). Movement of heavy metals through undisturbed and homogenized soil columns. Soil Science, 161, 40-750. http://dx.doi.org/10.1097/00010694-199611000-00003

Casali, C. A., Freire Moterle, D., dos Santos Rheinheimer, D., Brunetto, G., Mello Corcini, A. L., Kaminski, J., \& Wellington Bastos de Melo, G. (2008). Formas e dessorção de cobre em solos cultivados com videira na serra gaúcha do rio grande do sul. Revista Brasileira de Ciência do Solo, 3, 1479-1487. http://dx.doi.org/10.1590/S0100-06832008000400012

Conant, R. T., Ryan, M. G., Ågren, G. I., Birge, H. E., Davidson, E. A., Eliasson, P. E., ... Bradford, M. A. (2011). Temperature and soil organic matter decomposition rates - Synthesis of current knowledge and a way forward. Global Change Biology, 17, 3392-3404. http://dx.doi.org/10.1111/j.1365-2486.2011.02496.x

Ejhed, H., Zakrisson, J., Ryegård, A., Liljeberg, M., Westling, O., Munthe, J., ... Karlsson, B. (2005). Uppskattning av utsläpp för $\mathrm{Cd}, \mathrm{Hg}, \mathrm{Cu}$ och Zn på TRK-områden. Slutrapport januari 2005 Publication A1439 SMED. Norrköping, Sweden: SMHI. Retrieved from http://www.vattenmyndigheterna.se/SiteCollectionDocuments/sv/bottenviken/beslut-fp/underlagsmaterial/S 
MED_Metaller.pdf

European Chemicals Agency. (2008). Guidance on information requirements and chemical safety assessment. Appendix R.7.13-2: Environmental risk assessment for metals and metal compounds. Helsinki, Finland: European Chemicals Agency. Retrieved from http://echa.europa.eu/documents/10162/13632/information_re quirements_r7_13_2_en.pdf

European Environment Agency. (2015). The European environment - State and outlook 2015. Copenhagen: European Environment Agency. Retrieved from http://www.eea.europa.eu/soer

European Union. (2000). Water Framework Directive. Retrieved from http://ec.europa.eu/environment/water/wa ter-framework/index_en.html

European Union. (2006). Groundwater Directive. Retrieved from http://eur-lex.europa.eu/legal-content/EN/TXT /?uri=CELEX:32006L0118

Fernandez, C., Labanowski, J., Cambier, P., Jongmans, A. G., \& Van Oort, F. (2007). Fate of airborne metal pollution in soils as related to agricultural management. $1 . \mathrm{Zn}$ and $\mathrm{Pb}$ distributions in soil profiles. European Journal of Soil Science, 58, 547-559. http://dx.doi.org/10.1111/j.1365-2389.2006.00827.x

Food and Agriculture Organization. (2004). Carbon sequestration in dryland soils. World soils resources reports 102. Rome: Food and Agriculture Organisation. Retrieved from http://www.fao.org/docrep/007/y5738e/y5738e00.htm

Goodyear, A. (2011). Silver in Stockholm harbour water and sediment comparison of the input from biocides and other sources. Silver position paper. Knaresborough, North Yorkshire, UK: TSGE.

Groenenberg, J. E., Römkens, P. F. A. M., \& de Fries, W. (2006). Prediction of the long term accumulation and leaching of copper in Dutch agricultural soils; a risk assessment study. Alterra-report 1278. Wageningen, The Netherlands: Alterra. Retrieved from http://edepot.wur.n1/41912

Handl, J., Kallweit, E., Henning, M., \& Szwec, L. (2000). On the long-term behaviour of $110 \mathrm{mAg}$ in the soil-plant system and its transfer from feed to pig. Journal of Environmental Radioactivity, 48, 15-170 http://dx.doi.org/10.1016/S0265-931X(99)00066-1

He, Z., Endale, D. M., Schomberg, H. H., \& Jenkins, M. B. (2009). Total phosphorus. zinc. copper. and manganese concentrations in Cecil soil through 10 years of poultry litter application. Soil Science, 174 , 687-695. http://dx.doi.org/10.1097/SS.0b013e3181c30821

International Agency for Research on Cancer. (2012). IARC Monographs on the Evaluation of Carcinogenic Risks to Humans Volume 100C Arsenic, Metals, Fibres and Dusts. Geneva: World Health Organisation. Retrieved from http://monographs.iarc.fr/ENG/Monographs/vol100C/mono100C.pdf

Jardim Junior, A. M., Imbroisi, D., Nogueira, J. M., \& Zuchi da Conceição, P. H. (2012). Economics of wastewater treatment: Cost-effectiveness, social gains and environmental standards. Environmental Economics, 3(3), 17-32. Retrieved from http://businessperspectives.org/journals_free/ee/2012/ee_2012_03_ Junior.pdf

Jarvis, N. J., Taylor, A., Larsbo, M., Etana, A., \& Rosén, K. (2010). Modelling the effects of bioturbation on the re-distribution of 137Cs in an undisturbed grassland soil. European Journal of Soil Science, 61, 24-34 http://dx.doi.org/10.1111/j.1365-2389.2009.01209.x

Labanowski, J., Monna, F., Bermond, A., Cambier, P., Fernandez, C., Lamy, I., \& van Oort, F. (2008). Kinetic extractions to assess mobilization of $\mathrm{Zn}, \mathrm{Pb}, \mathrm{Cu}$, and $\mathrm{Cd}$ in a metal-contaminated soil: EDTA vs citrate. Environmental Pollution, 152, 693-701. http://dx.doi.org/10.1016/j.envpol.2007.06.054

Lepage, H., Evrard, O., Onda, Y., Patin, J., Chartin, C., Lefèvre, I., ... Ayrault, S. (2014). Environmental mobility of $110 \mathrm{mAg}$ : lessons learnt from Fukushima accident (Japan) and potential use for tracking the dispersion of contamination within coastal catchments. Journal of Environmental Radioactivity, 130, 44-55. http://dx.doi.org/10.1016/j.jenvrad.2013.12.011

Li, Z., \& Shuman, L. M. (1997). Mobility of $\mathrm{Zn}, \mathrm{Cd}$ and $\mathrm{Pb}$ in soils as affected by poultry litter extract- $\mathrm{I}$. leaching in soil columns. Environmental Pollution, 95, 219-226. http://dx.doi.org/10.1016/S0269-7491(96)00077-2

Lorenzoni, P., Valboa, G., Papini, R., Paone, R., Aramini, G., Colloca, C., \& Corea, A. M. (2007). Soil copper and zinc accumulation and bioavailability under a long term vineyard cultivation in south Italy. Italian Journal of Agronomy, 2, 31-39. http://dx.doi.org/10.4081/ija.2007.31 
Mantovani, A. (2009). Composicão química de solos contaminados por cobre: Formas, sorcão e efeito no desenvolvimento de espécies vegetais (Doctoral dissertation, Universidade Federal do Rio Grande do Sul, Porto Alegre, Brazil). Retrieved from http://www.lume.ufrgs.br/bitstream/handle/10183/17085/000710287. pdf? sequence $=1$

Matisoff, G., Ketterer, M. E., Rosén, K., Mietelski, J. W., Vitko, L. F., Persson, H., \& Lokas, E. (2011). Downward migration of Chernobyl-derived radionuclides in soils in Poland and Sweden. Applied Geochemistry, 26, 105-115. http://dx.doi.org/10.1016/j.apgeochem.2010.11.007

Mighall, T. M., Abrahams, P. W., Grattan, J. P., Hayes, D., Timberlake, S., \& Forsyth, S. (2009). Geochemical evidence for atmospheric pollution derived from prehistoric copper mining at Copa Hill, Cwmystwyth, mid-Wales, UK. Science of The Total Environment, 292, 69-80. http://dx.doi.org/10.1016/S0048-9697(02)00027-X

Miotto, A. (2012). Cobre em solos arenosos sob vinhedos e resposta bioquímica-fisiológica de videiras em produção (Doctoral dissertation, Universidade Federal de Santa Maria, Santa Maria, Brazil). Retrieved from http://w3.ufsm.br/ppgcs/disserta\%E7\%F5es\%20e\%20teses/teses/Alcione\%20Miotto_Tese $\% 20 \mathrm{de} \% 20$ Doutorado.pdf

Mirlean, N., Roisenberg, A., \& Chies, J. O. (2007). Metal contamination of vineyard soils in wet subtropics (southern Brazil). Environmental Pollution, 149, 10-17.

Organisation for Economic Co-operation and Development. (2008). Measuring material flows and resource productivity (Volume I). The OECD Guide. Paris: OECD. Retrieved from http://www.oecd.org/environment/indicators-modelling-outlooks/MFA-Guide.pdf

Palfrey, R. (2011). The Regulatory Framework and the Evidence Base, Presentation at CIWEM-CMS meeting 28 June 2011. Retrieved from http://www.ciwem.org/media/371874/Roderick\%20Palfrey.pdf

Périé, C., \& Ouimet, R. (2008). Organic carbon. organic matter and bulk density relationships in boreal forest soils. Canadian Journal of Soil Science, 88, 315-325.

Peters, A., Simpson, P., Merrington, G., Rothenbacher, K., \& Sturdy, L. (2011). Occurrence and Concentration of Dissolved Silver in Rivers in England and Wales. Bulletin of Environmental Contamination and Toxicology, $86,637-641$.

Rajesh, C. R., Reddy, K. S., Naidu, M. V. S., \& Ramavataram, N. (2003). Production and evaluation of compost and vermicompost from solid organic wastes. Asian Journal of Microbiology, Biotechnology, and Environmental Science, 5, 307-31. Retrieved from http://www.researchgate.net/publication/236025282_Pro duction_and_evaluation_of_composts_and_vermicomposts_from_solid_organic_wastes

Römkens, P. F. A. M., Bonten, L. T. C., \& Rietra, R. P. J. J. (2004). Copper leaching from soils: an inventory of available data and model concepts. Alterra-report 1031. Wageningen, The Netherlands: Alterra.

Salminen, B. (Ed.). (2015, September 13). Geochemical Atlas of Europe (Part 1, Statistics. Electronic version). Retrieved from http://weppi.gtk.fi/publ/foregsatlas/article.php?id=15

Simeonov, L. I., Kochubovski, M. V., \& Simeonova, B. G. (Eds.). (2011). Environmental heavy metal pollution and effects on child mental development. Risk assessment and prevention strategies. NATO Science for Peace and Security Series C: Environmental Security. Berlin, Germany: Springer Science+Business Media B.V. http://dx.doi.org/10.1007/978-94-007-0253-0_1

Svenskt Vatten. (2015). REVAQ Renare vatten -bättre kretslopp. Regler för certifieringssystemet. Stockholm, Sweden: Svenskt Vatten. Retrieved from http://www.svensktvatten.se/Documents/Kategorier/Avlopp\%20oc h\%20milj\%c3\%b6/REVAQ/Revaq-regler\%202015\%203.2.pdf

Svenson, A., Viktor, T., Palm-Cousins, A., Kaj, L., Woldegiorgis, A., Brorström-Lundén, E., \& Uggerud, T. (2013). Results from the Swedish National Screening Programme 2007 - Sub-report 5: Silver. Rapport B1826 (Revised version with corrections). Stockholm, Sweden: IVL Swedish Environmental Research Institute. Retrieved from http://www.ivl.se/download/18.21d4e98614280ba6d9e234d/1386667992303/B18 26_ver2_EBL.pdf

Sveriges Geologiska Undersökning. (2013). Bedömningsgrunder för grundvatten. SGU-rapport 2013 : 01. Uppsala, Sweden: Sveriges Geologiska Undersökning. Retrieved from http://resource.sgu.se/produkter/sgurapp/s1301-rapport.pdf

Tiecher, T. L., Ceretta, C. A., Comin, J. J., Girotto, E., Miotto, A., Pires de Moraes, M., \& Brunetto, G. (2013). 
Forms and accumulation of copper and zinc in a sandy Typic Hapludalf soil after long-term application of pig slurry and deep litter. Revista Brasileira de Ciencias do Solo, 37, 812-824.

United Nations Environment Programme. (2013). Environmental risks and challenges of anthropogenic metals flows and cycles. Nairobi: UNEP. Retrieved from http://www.unep.org/resourcepanel-old/Portals/24102/PD Fs/Environmental_Challenges_Metals-Full\%20Report_150dpi_13092

\section{Appendix}

[The headings used below are those of the basic article. References listed in the basic article are not re-listed here, they are given in italics.]

\subsection{Many Metals Are Assumed to Remain in the Topsoil But Do They Instead Pass through to Groundwater?}

Issues around metals from sludge amendent are economically and environmentally important and have a bearing on wider questions about the fate of metals in the environment. Decisions should be informed by the best possible knowledge. But there is little quantitative information on metal transport through soil.

$>$ Broader reviews of metals in the environment (International Council on Metals and Mining, 2007; United Nations Environment Program, 2013) tend to pay much attention to metal chemistry and bioavailability but not to transport through soil.

$>$ Overviews specialized on metals in soil enumerate factors that determine mobility and bioavailability in soil but do not give quantitative transport estimates (Azevedo Silveira, Ferracciú Alleoni, \& Guimarães Guilherme, 2003; Torri \& Corrêa, 2012; Violante, Cozzolino, Perelomov, Caporale \& Pigna, 2010; Smith, 2009; Alloway, 2013). Sometimes the focus is on soil chemistry and effects on soil related organisms (DEFRA, 2007).

$>$ Some reviews discuss quantitative estimates of the transport of metals over very large land areas (Ejhed et al., 2010; Bonten \& Groenenberg, 2008). However, they are based on rather limited empirical evidence of leaching through topsoil.

$>$ Some transport mechanisms have been reviewed in detail such as via colloids (Bradford \& Torkzaban, 2007; Karathanasis \& Johnson, 2006; Kretzschmar \& Schäfer, 2005; Bin, Cao, Dong, Luo, \& Ma, 2011; Weber, Voegelin, Kaegi, \& Kretzschmar, 2009), earthworms (Sizmur \& Hodson, 2009; Usmani \& Kumar, 2015) and other biological processes (Bespalova, Motuzova, \& Marfenina, 2002; Ioveni \& Bååth, 2008).

$>$ Organic matter is very important and has been reviewed in general (Rumpel \& Kögel-Knabner, 2011) or with respect to microrganisms (Lamy, 2006), or for specific metals such as copper (Oorts, 2013). Again quantitative transport is not addressed.

$>$ A major review discusses risks of groundwater contamination (Ritter et al., 2002) but stays with relative risks of various contaminant, not quantitative leaching.

There is conflicting information as to whether metals are really transported through the topsoil $(\mathrm{Lu}, \mathrm{He}, \&$ Stoffella, 2012). McGrath and Lane (1989) found no accumulation of some metals at deeper horisons after long term sludge amendment. Dowdy, Latterell, Hinesly, Grossman, and Sullivan (1991) did not find copper of sludge origin in the subsoil and quoted two other studies with similar results; they only recovered about one-half of applied cadmium and zinc, and suggested this was due to incomplete extraction for which they used 4.0 M $\mathrm{HNO}_{3}$. Sukkariyah, Evanylo, Zelazny, and Chaney (2005) described an apparent lack of trace metal leaching to more than $10 \mathrm{~cm}$ below the Ap horizon and found support for this in several other studies. Neither did Baveye et al. (1999) find accumulation at deeper horizons, but still budget calculations indicated a deficit in the topsoil metal contents. However, the large geographical scale studies mentioned above (Ejhed et al., 2010; Bonten \& Groenenberg, 2008) show clear indications of loss from topsoil. On a more local scale, clear leakage through soil to groundwater was demonstrated for metals in atmospheric fallout (Shotyk, Krachler, Aeschbach-Hertig, Hillier, \& Zheng, 2010). The perception of little loss from topsoil is in line with the assumption (Naturvårdsverket, 2013) that metals are accumulated in soil over centuries without any significant loss. In that case, protection of the soil organisms becomes the main purpose of restricting metal addition to soil. If instead many metals are transported through tilled soil in a time scale of a century, the medium to be protected may not be the soil but the groundwater, and a new paradigm for protection may need to be developed.

This has been a brief review of existing research. It is obvious that metal penetration through soil is very complex and dependent on a multitude of chemical, biological and other factors. It is to be expected that any resolution to the conflicting findings needs to take a large number of parameters into account and requires a relatively lengthy discussion. 


\section{Method}

\subsection{Overview Concerning Metal Penetration in Topsoil}

Copper is bearing many similarities to silver. It is next to silver in Group 11 of the periodic system of elements, and might be interesting as a silver analogue for soil mobility. The median partitioning coefficient soil/water was nearly the same for silver and copper whereas it was higher by a factor of 2 or more for other metals like cadmium, chromium(III) and lead (J. D. Allison \& T. L. Allison, 2005). An indication of similar environmental fate for copper and silver comes from studies of metals in soil, originating from irrigation with sewage effluent over a time scale of more than a century (Lottermoser, 2012). Soil levels exhibited an extremely close correlation between silver and copper (correlation coefficient 0.99); only silver, copper and zinc showed such close correlation. This would seem unlikely if the two metals had very different patterns of downward migration.

\subsection{Criteria for Eligibility}

\subsubsection{Clearly Enhanced Metal Levels}

If the background levels of the metals have existed for many decades in the soils, they can be expected to be tightly bound to soil constituents. This does not mean they are immobile. In fact several case studies suggest that the background copper is lost from the topsoil at a rate of 0.5-1.0\%/year (see below 3.3 Penetration of Metals in Control Soils). Only a small part of this loss should be due to plant removal, about $0.01 \% /$ year (Sukkariyah, Evanylo, Zelazny, \& Chaney, 2005). The loss means that over a few decades, about $10-20 \%$ of the background metal may be lost. For this reason, only those cases where the amended metal concentrations in topsoil are higher than the background concentrations are selected; this is to reduce the uncertainty of transport estimates concerning the amended concentrations. On this ground several studies have been deselected, such as Barreto, do Nascimento, de Medeiros, da Nóbrega, and Bezerra (2013), de Boer et al. (2012), Chino et al. (1992), Lorenzoni et al. (2007) (Cu1 and Cu16 cases), and Mantovi, Baldoni, Dal Re, Piccinini, and Rossi (2006).

To underline the importance of this criterion, two examples illustrate that the initial material in the soil may be mobilized by addition of organic matter. The first example refers to mobilization of soil organic matter itself. Organic matter is lost from deeper soil layers after addition of pig slurry rich in organic matter.

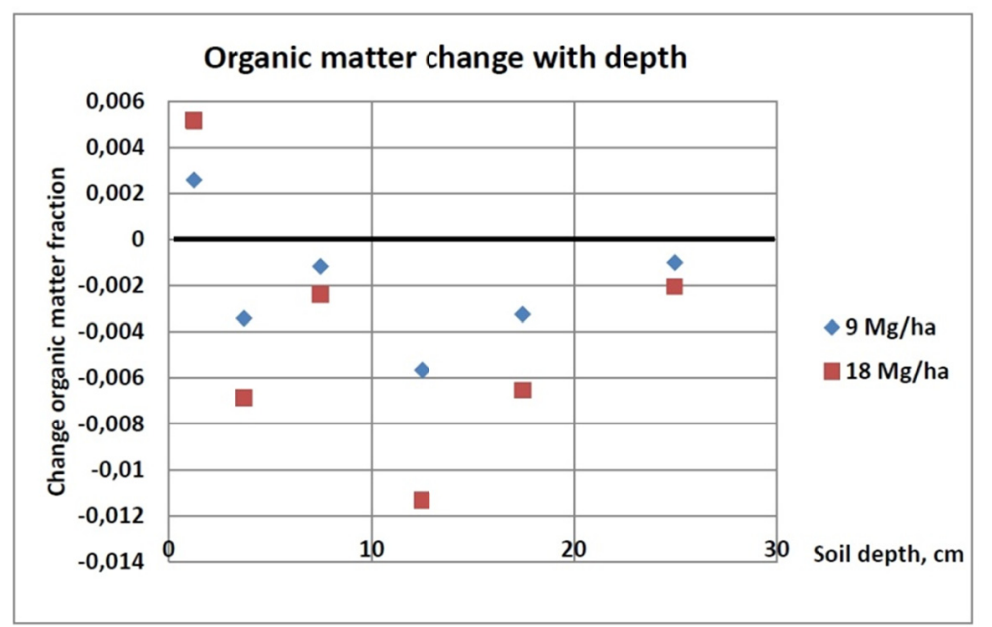

Figure S1. Organic matter may be lost from the subsoil following organic amendment

Note. Figure S1 shows the change of the organic matter fraction compared to control after surface application of pig slurry. The cases are amendment over 7 years with a total of $9 \mathrm{Mg} / \mathrm{ha}$ and $18 \mathrm{Mg} / \mathrm{ha}$ of dry organic matter, respectively (Guardini et al., 2012). Only at the very surface did the amendment lead to increased soil organic matter, whereas below there was a deficit. The deficit in organic matter for the higher amendment is considerably enhanced compared with that if the lower amendment.

The second example refers to mobilization of copper (Figure S2). Copper levels are enhanced in superficial soil layers but are lost from deeper soil layers after addition of pig slurry rich in organic matter and copper. 


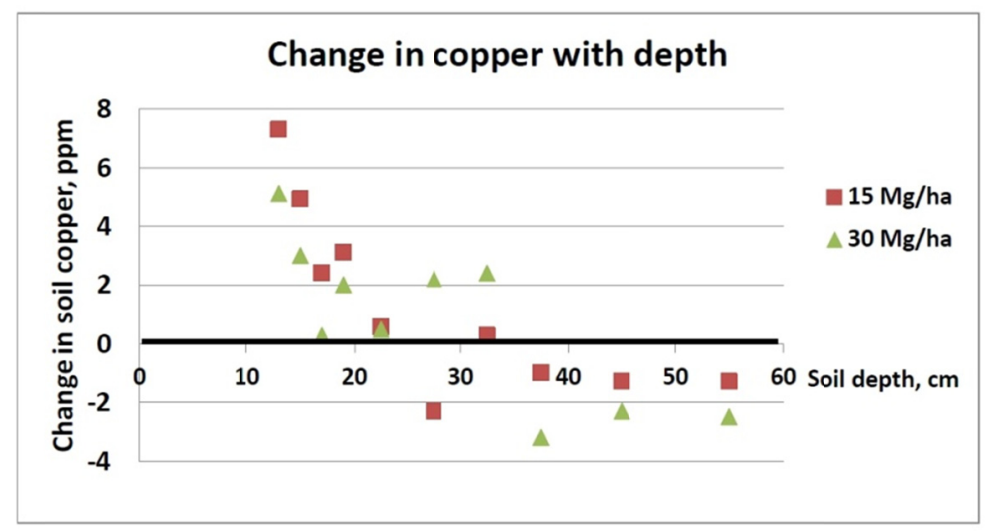

Figure S2. Metal may be lost from the subsoil following organic amendment

Note. The figure shows the change of the copper content in soil compared to control after surface application $\mathrm{f}$ pig slurry. The cases are amendment over 7 years with a total of $15 \mathrm{Mg} / \mathrm{ha}$ and $30 \mathrm{Mg} / \mathrm{ha}$ of dry organic matter, respectively (Girotto et al., 2012). At the surface the amendment lead to increased net soil copper, whereas below about $20 \mathrm{~cm}$ depth there was a deficit. The deficit in copper for the higher amendment is enhanced compared with that of the lower amendment. The background copper level was about $27 \mathrm{mg} / \mathrm{kg}$. The net copper level at the soil surface was about $60 \mathrm{mg} / \mathrm{kg}$ for an amendment of $30 \mathrm{Mg} / \mathrm{ha}$ dry organic matter.

\subsection{Parameters of Interest and Assumptions Made}

\subsubsection{Precipitation}

Precipitation has been assumed to control the downward movement of metals in the soil. However, the flow of water through the soil is a complex resultant of downward and upward movement (Jacques, Simunek, Mallants, $\&$ van Genuchten, 2008), with the amount of evapotranspiration varying strongly between climatic zones. The assumption that downward movement is proportional to the amount of precipitation is therefore likely an over-simplification. If precipitation information has not been available in the reports, data for the nearest larger village or city has been gathered from Internet searches.

\subsubsection{Speciation and Organic Binding}

\section{1) Metal Binding to Organic Matter}

In general, soil organic matter dominates specific copper adsorption in soil and is mainly responsible for retaining adsorbed copper (Altaher, 2001; Oorts, 2013). The sorption takes place in days (Burton, 2005; Betianu, 2007) and desorption-resorption may follow, subject to substantial hysteresis (Wu, Laird, \& Thompson, 1999). Fulvic acids and total organic carbon account for the transport of copper through soil columns (Altaher et al., 2011). Biological processes may be strongly involved (Bespalova, 2002; Ioveni, 2008). An extreme case is copper bound in isolated (ombrotrophic) peat, where the copper can be bound for millennia (Mighall et al., 2009) and thus be completely immobile. Organic matter is often strongly correlated with soil total copper contents. For instance, Flores Delgadillo et al. 1992 found a very strong linear relation with coefficient of determination 0.95.

Under changing conditions, the copper can be strongly bound to minerals (Oorts, 2013). In laboratory studies, dissolved organic matter is strongly sorbed on clay minerals and oxides. However, these high sorption values are not reproduced in limited field studies (Deb \& Shukla, 2011).

Metal complexes released from surface soils, where biological activity is high, may leach into subsoils and be less strongly retained by mineral surfaces there, explaining the low subsoil concentrations of heavy metals discussed in Subsection 1.3 above. (The subsoil often has only one-tenth or so of the organic matter level of the topsoil). The elemental and isotopic evidence suggests that soil organic matter in subsoils is more microbially processed than topsoil organic matter and most probably has a higher proportion of microbial derived compounds (Rumpel \& Kögel-Knabner, 2011).

2) Organic Matter Balance in the Topsoil

Organic matter in $20 \mathrm{~cm}$ topsoil is about $50 \mathrm{Mg} /$ hectare at the commonly occurring organic fraction of 0.02 and density $1337 \mathrm{~kg} / \mathrm{m}^{3}$. There is a general decrease towards deeper soil layers. Organic matter is formed and decomposed over the year. Formation often has a peak near the end of the growing season, e.g. August in the 
Northern hemisphere. One-third to one-half of the organic matter may be decomposed in a year (USDA-NRCS 2014).

Often the net result of formation and decomposition is a small long term loss. The loss could be of two kinds:

$>$ Mineralisation where the organic matter is dissolved into its elemental components;

> Transfer, mainly to the subsoil. Four main sources of organic matter input into subsoils have been identified: plant roots, root exudates, dissolved organic matter and bioturbation. In addition there may be translocation of particulate organic matter and transport of clay-bound organic matter in certain soil types (Rumpel \& Kögel-Knabner, 2011).

Long term studies in unamended soils often show a loss of organic matter, as exemplified by the reference to Barré et al. (2010) in the basic article. In a further analysis, the cases described by Barré et al. (2010) have been augmented by others to a total of 16 cases with durations from 29 to 168 years. These took place at Askov, Bad Lauchstadt, Grignon, Kursk, Morrow, Müncheberger, Rothamstead, Ruzyne, Thyrow, Ultuna and Versailles (details not given here). The mean loss rate in the organic fraction of the soil mass was 0.0076 per year with 700 $\mathrm{mm}$ precipitation, with a standard deviation of 0.0034 .

In contrast, sometimes with suitable fertilizing conditions, there may be a long term organic matter increase in the topsoil that may reach $4 \mathrm{Mg}$ /hectare and year (Andersson, 2012, after average amendment at Igelösa with 3 $\mathrm{Mg} / \mathrm{hectare}$ and year of sewage sludge) or even $8 \mathrm{Mg} /$ hectare and year (Kwon et al., 2013 after amendment with $50 \mathrm{Mg} /$ hectare and year of alcohol fermentation processing sludge). Such an increase combined with the metal affinity for organic matter complicates the metal balance calculations.

Where organic matter is important, there may be large heterogeneities in the level of organic matter at the mm scale, associated with corresponding heterogeneities of metal levels (Jacobson, Dousset, Andreux, \& Baveye, 2007).

The current paper studies to what extent the organic link to losses of copper and silver may be applicable to other metals.

\section{3) Ageing}

Ageing refers to the processes by which the mobility and bioavailability/toxicity of metals added to soil decline with time. The adverse effect of an elevated metal concentration may be more pronounced in spiked soils than in historically contaminated field soils at the same total metal level (McLaughlin et al., 2010; Settimio et al., 2014). This may i.a. depend on the degree of availability of the copper. Fresh copper that is added to old organically amended soil is less available in the next few days than fresh copper added to unamended soils (Smolders et al., 2012). The relative availability (amended/spiked) increases with the age of the amendment. This has more to do with the binding in spiked soils becoming harder with amendment age, than with any change in binding for the amended soils. Over 12 weeks, copper binding in sludge-amended soils did not change over time whereas the binding became tighter in metal-spiked soils (Natal-da-Luz et al., 2012). Although not measured directly, it is inferred from soil physicochemical controls on copper ageing that processes of precipitation/nucleation of copper in soils and hydrolysis of $\mathrm{Cu} 2+$ followed by a diffusion process controlled the decrease in copper availability with time (Ma, Lombi, Oliver, Nolan, \& McLaughlin, 2006).

\section{4) Assumptions for the Current Analysis}

Deficiencies in the Loss on Ignition method. The organic matter content was earlier often equated with the weight loss that followed burning of the soil sample at high temperature, using the Loss On Ignition method, LOI. Later research has shown that LOI often strongly overestimates the organic matter content, and the method has been seriously questioned: "While not suitable for determination where high accuracy is required, determination of organic carbon through LOI is likely suitable for exploratory soil surveys where rough estimation of organic matter is required" (Salehi, Hashemi Beni, Beigi Harchegani, Esfandiarpour Borujeni \& Motaghian, 2011). The earlier often used temperatures of $500{ }^{\circ} \mathrm{C}$ to $600{ }^{\circ} \mathrm{C}$ have now been replaced by $360{ }^{\circ} \mathrm{C}$ (North Central Regional Research, 1998, Salehi et al., 2011). This temperature was identified as optimum as it burnt most organic carbon, destroyed less inorganic carbon, caused less clay structural water loss, and used less electrical energy. For the present calculations, LOI results have been corrected using the data by Storer (1984) for organic matter less than $9.9 \%$ and by Goldin (1987) for mineral soils, as referenced by North Central Regional Research, 1998. At temperatures between $500{ }^{\circ} \mathrm{C}$ and $600{ }^{\circ} \mathrm{C}$ interpolation has been used.

Organic matter and organic carbon are strongly related. Soil organic matter contains approximately 58\% of carbon; therefore, a factor of 1.72 has been used to convert organic carbon content to content of soil organic 
matter (North Central Regional Research, 1998).

Total and organic carbon. Sometimes total carbon is measured, including inorganic carbon. The latter is usually less than $2 \%$ by weight of the soil, subject to large variations. In the present analysis, when only total carbon data were available, the organic carbon level has been approximated with the total carbon content.

Ageing. The process of ageing mainly takes place in time periods less than a year, and has been assumed to have negligible influence on multi-year metal penetration in topsoil.

Copper in manure. Sometimes enhanced copper levels were found in the background soils. To assess the possible influence of manure, a copper level of $70 \mathrm{mg} / \mathrm{kg}$ in manure was used, derived from Xiong, Li, Li, Lin, Han, and Yang (2010), (11-132 mg/kg), and Menzi and Kessler (1998), (19-119 mg/kg).

\subsubsection{Sand Content}

Very limited literature data indicate that soil solution copper contents are weakly correlated with the clay contents of the soil, with higher clay contents giving slightly larger potential for leakage from the soil (Römkens, Bonten \& Rietra, 2004). The present analysis assumes that the penetration in topsoil can be accounted for by using the sand level as the only soil texture parameter. Clay and silt need thus not enter into the penetration equation. Often for field studies, data on the topsoil fractions of sand, silt and clay are available, at least in a supplementary publication from the relevant research group. If this was not the case, the USDA soil texture triangle was used for estimation of default values for the sand fraction of the soil. Several definitions of particle size for sand are used in the literature. The currently used definition of sand entails grain sizes between 0.074 $\mathrm{mm}$ and $2 \mathrm{~mm}$.

Two processes related to the sand fraction have been assumed:

a) The first is an obstruction process due to clay and silt. These prevent deeper penetration. If sand is available, it facilitates downward movement of the organic matter with the metals, and penetration increases with the sand fraction $s$.

b) The second process involves strong fixation of the metals as mineral or organic compounds in the sand. With increasing sand fractions, this process takes over and eventually much metal is relatively tightly bound in pure sand. Since metal cannot be transferred to the organic matter fraction $o$, the receiving fraction is assumed to be $s-o$. The penetration is assumed to increase with $1-s+o$.

The total sand dependence is then assumed to depend on both $s$ and $1-s+o$. Minimum variation among different studies was obtained with power functions for these two variables.

\subsubsection{Mean Time since Deposition}

Metals are assumed to be transported in soil solution in the form of e.g. colloids or organic complexes. The soil solution is assumed to move down in the soil with percolated water from precipitation. The penetration depth is assumed to depend on the accumulated precipitation for all years of study.

For an initial assessment, the mean time since application is calculated from the periodically applied metal amounts through $\Sigma\left(\mathrm{D}^{*} \mathrm{~T}\right) / \Sigma(\mathrm{D})$, where $\Sigma\left(\mathrm{D}^{*} \mathrm{~T}\right)$ is the sum of the products of deposition amount and time, and $\Sigma(\mathrm{D})$ is the sum of the deposition amounts. If no detailed deposition data are available, the mean time is assumed to be half of the total application time, unless the deposition is single.

\section{Extrapolation to Different Times in the Decades Perspective}

If at time $t$ the loss of copper from a horizontal layer of the soil is proportional to the existing copper level $\mathrm{C}(t)$ and to the incremental time of leakage, the retention will decrease exponentially with time $\mathrm{t}: \mathrm{C}(t)=\mathrm{C}\left(\mathrm{t}_{0}\right) \mathrm{e}^{-\mathrm{k} t}$. Extracting k gives $\mathrm{k}=-\left(\ln \left(\mathrm{C}(t) / \mathrm{C}\left(\mathrm{t}_{0}\right)\right) / t\right.$. Relating the retentions at two different times $t$ and $t_{0}$ gives

$$
\left.\mathrm{C}(t)=\mathrm{e}^{(t / t)}\right)_{0}^{\ln C(t)}
$$

or in a simpler form

$$
\mathrm{C}(\mathrm{t})=\mathrm{C}\left(\mathrm{t}_{0}\right)^{\mathrm{t} / \mathrm{t}}
$$

The natural assumption about proportional loss is consistent with long term field experience as given by Sukkariyah, Evanylo, and Zelazny (2007). They studied the retention of copper in in two sites after 14 years of application of biosolids with measurements after 14 years and 21 years. Equation S1 has been used to transform the 14 year measurements to the 21 year measurement. For the site Acredale the measured retention in the layer $0-15 \mathrm{~cm}$ after 14 years was 0.71 of the supplied copper amount. The predicted retention after 21 years according to Equation S1 is 0.598 against the measured 0.59. For the site Bojac the corresponding numbers are $0.44,0.292$ 
and 0.29 . The prediction according to Equation $\mathrm{S} 1$ in these cases is thus very accurate.

\subsubsection{Displacement due to Agricultural Practices}

Surface application sometimes takes place on grass. In this case no displacement is assumed and the deposition is calculated to be at the very surface of the soil. In other cases, planting technology may lead to average displacement of the metal into the soil by less than a few centimeters. A corrected mean penetration depth is used: $d_{\text {corr }}=d-d_{t}$ where $d$ is the depth in the soil and $d_{t}$ is the displacement due to planting technology, both in cm. No displacement is assumed for no-till technology. In one case of harrowing (Lorenzoni et al., 2007), $2.5 \mathrm{~cm}$ displacement is assumed. Conventional tilling is normally assumed to achieve complete mixing over the tilling depth. This means that the average displacement of the surface applied metal is one half of the tilling depth.

\subsubsection{Acidity or Basicity, $\mathrm{pH}$}

At low $\mathrm{pH}$, copper generally leaks out of the soil more rapidly than at high $\mathrm{pH}$. Data are not consistent, however (Torri \& Correa, 2012) and the free ion fraction from experiments shows a spread over three decades (Oorts, 2013). Literature data often pool pH dependence with the influence of other factors. For instance, Römkens, Bonten, and Rietra (2004) use a rather weak $\mathrm{pH}$ dependence (to power 0.12).

A large number of laboratory tests on $\mathrm{pH}$ dependence have been made with sorption in soil solutions. These do not account for many of the mechanisms mentioned above under subsection 1.3, such as preferential pathways and earthworms. They may therefore confirm general trends but not numerically predict the $\mathrm{pH}$ dependence.

On the other hand, long term field studies suffer from the difficulty of many confounding factors at play at the same time, as enumerated in the basic article under subsection 2.3. Further, field study data often show a large variability due to the complexity of the soil processes.

Some guidance was found in the combination of two studies. Shang and Leung (2003) kept soil in a plastic container, thus with no vegetation providing for richer organic life. In that case, silver penetration exhibited a $\mathrm{pH}$ dependence (Shang \& Leung, 2003, Table 4) with the penetration at $\mathrm{pH}=4$ being 2.0 times that at $\mathrm{pH}=8$. The $\mathrm{pH}$ dependence is very uncertain. A similar $\mathrm{pH}$ dependence with a larger slope could be derived for a long term field study of copper at very high levels potentially disturbing organic life (Fan, He, Ma, \& Stoffella, 2011); this dependence was even more uncertain.

It is not at all clear that these two experiments are representative of what would happen in more complicated field studies. However, the two studies lead to the assumption of a linear dependence of penetration depth on $\mathrm{pH}$. After successive approximations to derive the penetration equation, a ratio of 2.2 was resulting for the penetration at $\mathrm{pH}=4$ as compared to $\mathrm{pH}=8$. Some other relationships were tested with poorer result. The chosen $\mathrm{pH}$ dependence is not inconsistent with those derived from the two mentioned studies.

According to Oorts (2013), there is also a weaker dependence of $\mathrm{pH}$ near and below $\mathrm{pH}=4$. Therefore, there should be a component providing a shoulder to the $\mathrm{pH}$ curve around $\mathrm{pH}=4$. Since so low values of $\mathrm{pH}$ are extremely rare in agriculture, no such shoulder was used.

\subsubsection{Depth Distributions in Soil}

In field studies, the metal is initially at a given depth $d$ in the soil. Often the case concerns surface deposition, that is, $\mathrm{d}=0$. In studies with little confounding, the depth distribution may be exponential, as exemplified in the studies of Miotto (2012), (Vineyards 2 and 3). The concentration $C(d)$ is initially assumed to decreases approximately exponentially with depth $d$ in the topsoil, that is

$$
\mathrm{C}(\mathrm{d})=\mathrm{e}^{-\mathrm{i}^{*} \mathrm{~d}}
$$

A simplistic view is that the copper follows the organic material at a rate determined by the flow of the percolated water. In this view, a front of copper moves down the soil at approximately a constant annual rate. Some information supports such a transition from an initial exponential depth distribution to a more defined, wide front moving down in the soil with time:

> Considering the many mechanisms at play including preferential pathways and earthworms, a natural assumption would be that there is a large spread in the annual penetration rate, and that the distribution of penetration depths is approximately lognormal. For instance, the penetration of silver in a grassland soil (Handl, Kallweit, Henning \& Szwec, 2000) can be used to fit a lognormal distribution with a standard deviation which is about the same as the mean penetration depth. As the front proceeds downward, it may be relatively more concentrated around the mean penetration depth. 
$>\quad$ Such a general progression was found in great detail for cesium in soil with extremely high organic matter content (the Hille case, Matisoff et al., 2011).

A similar progression was found by Benö, Facchinelli, Franchini Angela, and Fornelli Genot (2009). They studied a group of vineyards (C-ELO) that had been operated for 33 years and then abandoned for 8 years. In 3 out of 4 vineyards, the soil depth distribution of copper had a clear peak at about $20 \mathrm{~cm}$ depth.

The following assumptions were used in the present analysis:

$>$ In the initial phases of penetration of metals into soil, the depth distribution is approximately exponential.

$>\quad$ A surface deposition of metal is assumed to move down at a constant average rate. The mean depth is $1 / \mathrm{k}=$ $-d / \ln (1-F)$, where $d$ is the topsoil depth, $1 / \mathrm{k}$ is the relaxation length of the exponential distribution, and $\mathrm{F}$ is the fraction lost from the topsoil.

At larger depths, the tail of the depth distribution is exponential; this is used for extrapolation beyond the depth at which metal measurements have been made.

The mean penetration depths were thus calculated in two ways:

$>$ Starting from the measured metal fraction lost from the topsoil, assuming exponential depth distributions, or,

$>\quad$ Using the depth distributions in soil. When these had poor depth resolution, an exponential decrease with depth was assumed within the unresolved part. Note that depth distributions have to be used with much caution in view of the possible rapid transport through subsoil discussed in subsection 1.3; the loss at larger depths can easily be underestimated.

\subsubsection{Bulk Density}

A lower density may after amendment lead to higher metal levels ( $\mathrm{kg}$ metal per $\mathrm{kg}$ soil) in the topsoil than if the density were higher. This is because the topsoil has a given depth in centimeters, and the amended amount of metal is shared over a smaller mass of soil. In a more steady state, reduced density may lead to increased mean metal concentration over the sampling depth if the metal concentration decreases strongly with depth; if the concentration is relatively constant with depth, density changes will not affect the metal concentration.

The soil density may depend on the organic matter level in the soil. This may have physical as well as biological components.

$>$ Amendment with organic fertilizer may physically change the dry bulk density of the soil. For instance, the dry bulk density of sewage sludge is about $600 \mathrm{~kg} / \mathrm{m}^{3}$, with large variations. If $100 \mathrm{Mg}$ per hectare of such sludge is deposited without incorporation onto a soil with dry bulk density of $1260 \mathrm{~kg} / \mathrm{m}^{3}$, the mass of the uppermost $10 \mathrm{~cm}$ of the soil would be reduced by $4 \%$. The same would hold if it were incorporated within these $10 \mathrm{~cm}$ without losing its structure. If the depth of $4 \mathrm{~cm}$ were instead chosen, the increase would be $10 \%$. These reductions are approximately consistent with a finding from a laboratory study. Here, addition of $100 \mathrm{Mg}$ of sludge per hectare to a sandy loam would imply about 5\% reduction in bulk density (Roudsary \& Pishdar, 2007).

$>\quad$ In reality, longer term biological mechanisms are substantially augmenting the density change. With organic amendment, a richer organic life can be expected. This could lead to soil structures such as burrows and worm trails which would facilitate penetration, and a rich root structure. The looser soil structure could lead to a lower soil bulk density meaning a lower soil mass for a given depth of the topsoil. For instance, the dry bulk density of a calcareous soil at $0-20 \mathrm{~cm}$ was reduced by several times more than derived from physical considerations only, after long term application of $100 \mathrm{Mton} / \mathrm{ha}$ of sewage sludge (Hemmat, Aghilinategh, Rezainejad, \& Sadeghi, 2010). Even without any large amendment, low densities occur.

The soil density may also depend on depth. For a silt loam used with irrigated cropping (Sojka, Busscher, \& Lehrsch, 2001), the dry bulk density increased by $0.6 \%$ per $\mathrm{cm}$ depth until $30 \mathrm{~cm}$ depth; the average covered sampling both after spring plowing, and after corn harvest before fall tillage. The dry bulk density at the surface was $1046 \mathrm{~kg} / \mathrm{m}^{3}$ and that at $30 \mathrm{~cm}$ depth $1223 \mathrm{~kg} / \mathrm{m}^{3}$. The mean organic matter content by mass over $0-28 \mathrm{~cm}$ depth was $1.7 \%$.

Several studies give bulk density as a function of organic matter content. A summary is given in Table S1. Indeed, the depth dependence may partly reflect the variation of organic matter with depth; often the organic matter content decreases with depth, consistent with an increase of density with depth. 
Table S1. Relation between soil density and organic matter level

\begin{tabular}{lllll}
\hline Soil type & Depth cm & $\begin{array}{l}\text { Density at 1\% } \\
\text { organic matter } \\
\left(\mathrm{kg} / \mathrm{m}^{3}\right)\end{array}$ & $\begin{array}{l}\text { Density at 3\% } \\
\text { organic matter } \\
\left(\mathrm{kg} / \mathrm{m}^{3}\right)\end{array}$ & Reference \\
\hline Crop sandy clay loam to sand & 15 & 1337 & 850 & $\begin{array}{l}\text { Chaudhari, Ahire, Ahire, Chkravarty, } \\
\text { and Maity (2013) }\end{array}$ \\
$\begin{array}{l}\text { Forest loam to sandy loam } \\
\text { Paddock varied soils }\end{array}$ & $0-100$ & 1539 & 1189 & Périé and Quimet (2007) \\
Varied soils & $0-10$ & 1596 & 1253 & Packer, Medway, Jones, and Koen (1998) \\
Varied soils & $5-15$ & 1600 & 1150 & Kilic, Agca, and Yalcin (2004) \\
& $0-25$ & 1728 & 1430 & Andrén, Kätterer, Karlsson, and Eriksson (2008) \\
\hline
\end{tabular}

The given densities in Table S1 have been extrapolated or interpolated from data stated in the publications. The complete data (not shown here) show good consistency between $0.5 \%$ and $5 \%$ organic matter contents for Kilic, Agca, and Yalcin (2004), Packer, Medway, Jones, and Koen (1998), and Périé and Quimet (2007). The data from Chaudhari, Ahire, Ahire, Chkravarty, and Maity (2013) give about $200 \mathrm{~kg} / \mathrm{m}^{3}$ lower densities. For the current article, the data of Périé and Quimet (2007) were used.

\subsubsection{Metal Levels}

There are reasons to believe that copper levels in topsoil above about $25000 \mathrm{mg} / \mathrm{kg}$ in the organic part of the soil could lead to changes in penetration of copper in the soil. This hypothesis was tested in the analysis of the set of data used to define the penetration equation. However, all variation of penetration could be described using the other parameters (exposure time, levels of precipitation, organic matter, $\mathrm{pH}$ and sand, and soil bulk density). Thus there was no need to apply the hypothesis about metal impact in any quantitative way. Still, the hypothesis is described here since the copper penetration seemed to depend strongly on the copper level before the other parameters were accounted for.

The argument was as follows, with the assumptions discussed first and thereafter detailed supporting data.

Since there is a large heterogeneity of organic matter and copper levels at the mm scale, copper levels at the microscale may be much higher than average copper levels. A first approximation to microbiologically interesting copper levels is to use the copper levels in organic matter. It is assumed that initially, all of a fresh supply of copper or silver will be contained in organic matter. At high metal levels, soil organic life is strongly affected. It is hypothesized that this leads to a relatively quick transfer from looser organically bound to more tightly bound metal, and this transition is controlled by the organically bound metal level. This would lead to much less metal penetration in the topsoil. The levels at which this transition would take place should begin at around $50 \mathrm{mg} / \mathrm{kg}$ average copper content in soil, and important effects should be seen at ten times this level. The lower of these levels for copper is only about twice the natural $90^{\text {th }}$ percentile copper level in soil in Europe. The corresponding levels of organically bound copper are $2500 \mathrm{mg} / \mathrm{kg}$ and $25000 \mathrm{mg} / \mathrm{kg}$ in a soil with $2 \%$ organic matter.

For silver there is no consensus about a no-effect level. In its absence the same relation to natural levels is assumed as for copper. With the $90^{\text {th }}$ percentile silver level in soil being $0.5 \mathrm{mg} / \mathrm{kg}$, an influence on soil organisms would then begin around a silver level of $1 \mathrm{mg} / \mathrm{kg}$ in the soil.

In some studies, other metals have been applied together with copper. For instance, copper in sludge is often supplemented by levels of cadmium and lead that give soil levels relatively high in comparison with natural soil levels. In such cases additional effects on soil organic life may interact with those of copper. Where other metals may be important the same background level analogy has been used; an equivalent copper level is used where metals are added in relation to their background levels compared to that of copper.

This analogy should not be stretched too far. It is known that soil organisms may adapt to their natural surrounding leading to a shift in the levels at which the soil is affected (the concept of metalloregion, Fairbrother $\&$ McLaughlin, 2002). Cases should be de-selected where the penetration in soil might be strongly affected by the actual metal levels.

The levels must apply to a sizeable share of all the metal in the soil, say one-half of it.

The data upon which the argument is based are further summarized below. 
No effect levels are often suggested around $50 \mathrm{mg} / \mathrm{kg}$ total copper in soil (European Union, 2011; Ippolito, Ducey, \& Tarkalson, 2011).

$>$ Severe effects on soil organisms have been studied as follows:

- Above $500 \mathrm{mg} / \mathrm{kg}$ it was not possible to grow alfalfa (Ippolito, Ducey, \& Tarkalson, 2011);

- A threshold level for copper was suggested $(\sim 500 \mathrm{mg} / \mathrm{kg})$ beyond which microbial activity decreases and soil structure becomes more compact with reduced permeability to air (Arthur et al., 2012);

- Vineyards are often abandoned at higher copper levels;

- "Moreover, there was an inverse relation between burrowing activity and soil bulk density that could also be related to the copper content. This may lead to a decrease in sustainable soil quality in vineyards" (Eijsackers, Benekec, Maboetac, Louwd, \& Reinecke, 2005);

- At levels of $553 \mathrm{mg}$ copper per $\mathrm{kg}, 90 \%$ avoidance of orchard soil by earthworms was observed (van Zwieten, Rusta, Kingston, Merrington, \& Morris, 2004).

\subsection{Penetration of Other Metals than Copper and Silver}

For other metals, a multiplier was applied to the penetration equation in order to explain the observed losses from the topsoil, or the penetration depths. Some details from the different cases are given in Table S2.

Table S2. Penetration depth of other metals in relation to copper

\begin{tabular}{|c|c|c|c|c|c|}
\hline First author (year) & Case & Sludge $\mathrm{Mg} /$ hectare & Years & Loss indicator & Cm depth \\
\hline Chaudri (1993) & $300 \mathrm{~m}^{3}$ & 160 & 10 & Mass balance & 20 \\
\hline Richards (1998) & Wick sampler & 244 & 15 & Depth profile & $25-50 / 0-50$ \\
\hline Brown (1997) & High $\mathrm{pH}$ & 50 & 17 & Mass balance & 20 \\
\hline Brown (1997) & Low $\mathrm{pH}$ & 100 & 17 & Mass balance & 20 \\
\hline Brown (1997) & High $\mathrm{pH}$ & 100 & 17 & Mass balance & 20 \\
\hline Yingming (1993) & Plano silt loam & 112 & 11 & Mass balance & 20 \\
\hline Stöven (2005)/Chaudri (1993) & $300 \mathrm{~m}^{3}$ & 132 & 13 & Difference 1991-2003 & 20 \\
\hline Barajas-A. (2005) & Single & 357 & $32 / 51$ & Diff. 1960-1991 & 23 \\
\hline Barajas-A. (2005) & Double & 714 & $32 / 51$ & Diff. 1960-1991 & 23 \\
\hline Schroder (2008) & $\begin{array}{l}\text { Mean of } 180 \text { and } \\
269 \mathrm{~kg} \mathrm{~N} / \mathrm{ha}\end{array}$ & 130 & 13 & Mass balance & 15 \\
\hline Schroder (2008) & $539 \mathrm{~kg} \mathrm{~N} / \mathrm{ha}$ & 312 & 13 & Mass balance & 15 \\
\hline Percival (2003) & $\begin{array}{l}\text { Mean of } \\
4 \text { spikes }\end{array}$ & 30 & 3 & Mass balance & 10 \\
\hline Michalk (1995) & 30 ton & 120 & 1 & Depth profile & $10-30 / 0-30$ \\
\hline Michalk (1995) & 120 ton & 120 & 1 & Depth profile & $10-30 / 0-30$ \\
\hline Sukkariyah (2005) & & 126 & 17 & Mass balance & 15 \\
\hline Sukkariyah (2005) & & 210 & 17 & Mass balance & 15 \\
\hline Lepage (2014) & & Pasture & 1 & Depth profile & 2 \\
\hline Rosén (1999) & Trödje & $\begin{array}{l}\text { Temporary pasture only } \\
\text { artificial fertiliser }\end{array}$ & 6 & $\begin{array}{l}\text { Depth profile compared with } \\
\text { penetration equation }\end{array}$ & $0-25$ \\
\hline Rosén (1999) & Ramvik & Permanent pasture & 1 & & $0-25$ \\
\hline Rosén (1999) & Ramvik & Permanent pasture & 10 & & $0-25$ \\
\hline Rosén (1999) & Hammarstrand & Permanent pasture & 3 & & $0-25$ \\
\hline Rosén (1999) & Hammarstrand & Permanent pasture & 9 & & $0-25$ \\
\hline Czarnecki (2015) & Mean 4 soils NPK & Only NPK; $10 \%$ o.m. & 0.25 & Diff.N-A 2000 & 30 \\
\hline \multicolumn{6}{|l|}{ Mean } \\
\hline \multicolumn{6}{|l|}{ Sample size } \\
\hline $95 \%$ confidence interval & & & & & \\
\hline
\end{tabular}


Table S2. Continue

\begin{tabular}{|c|c|c|c|c|c|c|c|c|c|}
\hline \multirow{2}{*}{ First author (year) } & \multicolumn{9}{|c|}{ Multiplier relative to that of copper or penetration equation } \\
\hline & $\mathrm{Cd}$ & $\mathrm{Ni}$ & $\mathrm{Pb}$ & $\mathrm{Mn}$ & $\mathrm{Zn}$ & Cs & Mo & $\mathrm{Cr}$ & All \\
\hline Chaudri (1993) & 1.00 & & & & & & & & \\
\hline Chaudri (1993) & 1.01 & & & & & & & & \\
\hline Richards (1998) & 0.96 & & & & 1.04 & & & 0.98 & \\
\hline Brown (1997) & & & & & 0.80 & & & & \\
\hline Brown (1997) & 1.32 & & & & 1.21 & & & & \\
\hline Brown (1997) & 1.42 & & & & 1.06 & & & & \\
\hline Yingming (1993) & 1.24 & & & & 0.76 & & & & \\
\hline Stöven (2005)/Chaudri (1993) & 1,30 & & 1,27 & & 0,94 & & & 1,11 & \\
\hline Barajas-A. (2005) & 0,79 & & 1,68 & & 0,59 & & & 0,89 & \\
\hline Barajas-A. (2005) & 0,93 & & 0,90 & & 0,82 & & & 0,96 & \\
\hline Schroder (2008) & & & & & 0.55 & & & & \\
\hline Schroder (2008) & & & 1.06 & & 0.76 & & 1.41 & & \\
\hline Percival (2003) & & 0.83 & & & 1.15 & & & & \\
\hline Michalk (1995) & & & & & 0.76 & & & & \\
\hline Michalk (1995) & & & & & 1.06 & & & & \\
\hline Sukkariyah (2005) & & & & & 0.87 & & & & \\
\hline Sukkariyah (2005) & & & & & 1.00 & & & & \\
\hline Lepage (2014) & & & & & & $0.81^{*}$ & & & \\
\hline Rosén (1999) & & & & & & 0.81 & & & \\
\hline Rosén (1999) & & & & & & 0.63 & & & \\
\hline Rosén (1999) & & & & & & 0.85 & & & \\
\hline Rosén (1999) & & & & & & 0.99 & & & \\
\hline Rosén (1999) & & & & & & 1.18 & & & \\
\hline Czarnecki (2015) & & & & 1.10 & & & & & \\
\hline Mean & 1,11 & $\mathbf{0 , 8 3}$ & 1,23 & 1,10 & 0,89 & 0,88 & 1,41 & 0,99 & 1,00 \\
\hline Sample size & 9 & 1 & 4 & 1 & 15 & 6 & 1 & 4 & 41 \\
\hline $95 \%$ confidence interval & $0,97-1,25$ & & $0,90-1,56$ & & $0,79-0,99$ & $0,73-1,03$ & & $0,90-1,08$ & $0,92-1,08$ \\
\hline
\end{tabular}

Note. *Reference is silver, not copper.

\subsection{Penetration of Metals in Control Soils}

With few exceptions the metal levels in control soils were decreasing with time. Table S3 gives the rate of decrease for the 12 cases analysed.

The table gives the details behind the summary table in the main article. The high multiplier of 1.68 for lead is not a chance statistical outlier, since a similar value was observed in the same study for another type of amendment, sludge-compost. 
Table S3. Fraction of metals lost from control soils per year of $700 \mathrm{~mm}$ precipitation

\begin{tabular}{llll}
\hline First author and year & Case & \multicolumn{2}{c}{ Fraction lost/year } \\
\cline { 3 - 4 } & & $\mathrm{Zn}$ & $\mathrm{Cu}$ \\
\hline Defra 2007 & Gleadthorpe & 0,009 & $-0,018$ \\
Defra 2007 & Woburn & 0,010 & 0,019 \\
Defra 2007 & Watlington & 0,017 & 0,049 \\
Defra 2007 & Pwellpeiran & 0,028 & 0,017 \\
Defra 2007 & Rosemaund & 0,013 & 0,023 \\
Defra 2007 & Bridgets & 0,027 & 0,038 \\
Defra 2007 & Hartwood & $-0,004$ & 0,009 \\
Defra 2007 & Auchincruive & 0,024 & 0,016 \\
Defra 2007 & Shirburn & 0,009 & 0,020 \\
Chino 1992 & & 0,003 & 0,003 \\
Andersson 2012 & Igelösa & & 0,006 \\
Andersson 2012 & Petersborg & & 0,007 \\
Average & & $\mathbf{0 , 0 1 4}$ & $\mathbf{0 , 0 1 8}$ \\
Sample size & & 10 & 12 \\
95\% confidence interval for average & & $0.007-0.020$ & $0.008-0.027$
\end{tabular}

The fraction of topsoil metal lost per year is the average over observation periods ranging from 11 years to 31 years. The loss is significantly different from 0 but the difference in loss between zinc and copper is not significant. The data based on Defra 2007 are quite variable but the overall tendency is similar to the one of Chino et al. (1992) and Andersson (2012), for which data are much less variable.

The mean penetration rate was about $3 \mathrm{~mm}$ per year of $700 \mathrm{~mm}$ precipitation, for both zinc and copper. The standard deviation was large, about the same as the average penetration. Because of the large uncertainties, no further analysis was considered meaningful. However, the uncorrected mean penetration rate was the same as the uncorrected mean penetration rate for the 11 cases used to derive the penetration equation. The latter, however, had a somewhat smaller standard deviation of $2 \mathrm{~mm}$ per year. For the Middle set of parameters (Subsection 3.1), the penetration equation gives a mean penetration of $5 \mathrm{~mm}$ per year for a mean time since deposition of 7 years.

It is interesting to compare the loss from control soils with the very long term loss of organic matter discussed above in subsection 2.3.2 under Organic matter balance in the topsoil. The mean relative loss rate in the organic fraction of the soil mass was the subject of many long term studies of unamended soils. The loss was 0.0076 per year with $700 \mathrm{~mm}$ precipitation, with a standard deviation of 0.0034 . This is about one-half of the mean loss rate of Table S3. It is also very near the loss rates of the studies of Table S3 with the longest duration, those of Andersson (2012) which lasted 31 years. The long term organic loss is broadly consistent with the picture that emerges from the penetration equation, with a more rapid loss the years following the creation of the organic matter and a slower loss in the decades thereafter. This may be another suggestion that the penetration equation indeed describes the fate of the organic matter.

\subsection{Penetration of Metals Following Unusually Large Amendments}

The studies behind Figure 2 of the basic article are detailed in Table S4. 
Table S4. Data from studies used to illustrate how organic amendment influences the penetration rate

\begin{tabular}{|c|c|c|c|c|c|c|c|c|c|c|c|c|c|}
\hline First author (year) & Case & 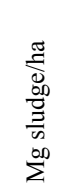 & $\mathrm{pH}$ & $\mathrm{s}$ & o & $\mathrm{p}$ & $\mathrm{t}$ & $\mathrm{d}$ & 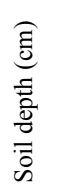 & 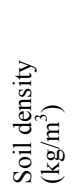 & 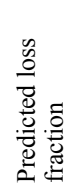 & 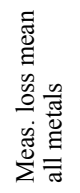 & 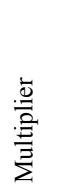 \\
\hline Brown (1997) & Christ. Low $\mathrm{pH}$ & 100 & 5.4 & 0.6 & 0.029 & 1063 & 17 & 6.86 & 20 & 1197 & 0.32 & 0.56 & 2.31 \\
\hline Brown (1997) & Christ. High pH & 100 & 6.25 & 0.6 & 0.029 & 1063 & 17 & 5.89 & 20 & 1197 & 0.28 & 0.49 & 2.15 \\
\hline Brown (1997) & Christ..Low pH & 50 & 5.4 & 0.6 & 0.025 & 1063 & 17 & 7.39 & 20 & 1256 & 0.33 & 0.36 & 1.13 \\
\hline Brown (1997) & Christ. High pH & 50 & 6.25 & 0.6 & 0.025 & 1063 & 17 & 6.34 & 20 & 1256 & 0.29 & 0.24 & 0.83 \\
\hline Brown (1997) & Christ. Mean 3 processes & 224 & 6.9 & 0.6 & 0.036 & 1063 & 19 & 4.95 & 20 & 1122 & 0.26 & 0.52 & 2.46 \\
\hline Brown (1997) & Galestown & 224 & 7.6 & 0.9 & 0.036 & 1063 & 19 & 2.78 & 20 & 1122 & 0.15 & 0.39 & 2.50 \\
\hline Brown (1997) & Galestown & 448 & 7.6 & 0.9 & 0.050 & 1063 & 19 & 2.47 & 20 & 989 & 0.15 & 0.61 & 5.70 \\
\hline Yingming (1993) & & 112 & 6.4 & 0.14 & 0.045 & 870 & 11 & 2.74 & 20 & 1310 & 0.14 & 0.14 & 1.03 \\
\hline Sukkariyah (2005) & & 126 & 5.7 & 0.15 & 0.032 & 1091 & 17 & 5.03 & 15 & 1164 & 0.37 & 0.45 & 1.53 \\
\hline Sukkariyah (2005) & & 210 & 5.7 & 0.15 & 0.040 & 1091 & 17 & 4.52 & 15 & 1076 & 0.37 & 0.53 & 1.57 \\
\hline Schroder (2009)* & Mean $180-269 \mathrm{~kg} \mathrm{~N} / \mathrm{ha}$ & 130 & 6.1 & 0.33 & 0.022 & 860 & 7.1 & 4.46 & 15 & 1297 & 0.30 & 0.45 & 1.70 \\
\hline Schroder (2009)* & $539 \mathrm{~kg} \mathrm{~N} / \mathrm{ha}$ & 313 & 6.1 & 0.33 & 0.027 & 860 & 7.1 & 4.07 & 15 & 1227 & 0.29 & 0.70 & 3.84 \\
\hline Percival* & Mean spikes 2, 3, 4 & 30 & 5.5 & 0.42 & 0.046 & 640 & 1.6 & 2.05 & 10 & 1016 & 0.27 & 0.26 & 0.95 \\
\hline Michalk (1995) & & 30 & 4.7 & 0.71 & 0.036 & 700 & 1 & 2.12 & 10 & 1117 & 0.25 & 0.43 & 1.86 \\
\hline Michalk (1995) & & 120 & 5.4 & 0.71 & 0.101 & 700 & 1 & 1.24 & 10 & 712 & 0.23 & 0.49 & 2.10 \\
\hline Ippolito (2009) & & 30 & 5.7 & 0.65 & 0.043 & 383 & 12 & 3.20 & 8 & 1052 & 0.40 & 0.32 & 0.74 \\
\hline Dowdy* & & 765 & 5.7 & 0.3 & 0.040 & 960 & 7 & 3.71 & 22 & 1076 & 0.21 & 0.50 & 3.05 \\
\hline Barajas-Aceves (2005)* & & 357 & 6.7 & 0.79 & 0.030 & 657 & 7.7 & 2.77 & 23 & 1189 & 0.14 & 0.33 & 2.53 \\
\hline Barajas-Aceves (2005)* & & 714 & 6.6 & 0.79 & 0.035 & 657 & 7.7 & 2.64 & 23 & 1129 & 0.14 & 0.56 & 4.88 \\
\hline
\end{tabular}

Note. The total organic amendment is given in $\mathrm{Mg} /$ hectare.The symbols for the parameters of the penetration equation are explained in the basic paper, Subsection 3.1. The studies marked with an asterisk* represent multiple amendments; all of the others used single amendments. Of the latter, Ippolito, Barbarick, and Brobst (2009), represents surface deposition, and Michalk, Curtis, Seaman, Langford, and Osborne (1995) represents partly tilled deposition.

One deselected case exhibited unusually large loss. This concerned the loss of several metals in Braunschweig between 1991 (Chaudri, McGrath, Giller, Rietz, \& Sauerbeck, 1993) and 2003 (Stöven, Al-Assa, Rogasik, Krdatz, \& Schnug, 2005). The case could not be analyzed because of a very complex history: an initial year with low amendment was followed by 10 years of extensive amendment, and after this the lots were turned into permanent pasture where the soil had strongly increasing organic matter content. It is likely that this increase was particularly high near the surface, while there may have been a decrease towards the lower end of the $20 \mathrm{~cm}$ measurement depth. While this complexity could not be modeled in quantitative terms, the penetration rate was consistent with a larger loss than that derived using the penetration equation. This would be expected since the total organic amendment was about $40-120 \mathrm{Mg}$ per hectare.

\subsection{Penetration of Metals Following Increases in Soil Organic Matter}

In a field study of sludge amendment over three decades (Andersson 2012), one soil (Igelösa) exhibited almost a doubling of the organic matter the first 15 years, while the other (Petersborg) had essentially constant organic matter content. This was concomitant with about half the rate of loss of copper from the topsoil at Igelösa relative to that of Petersborg. A potential explanation might be that the metal is more strongly retained if the organic matter increases. Unfortunately the data sets did not meet the selection criteria, with strong confounding from mobilization of background metal and from increased mobility due to unusually large amendment (12 Mg sludge per hectare every four years to a total of $96 \mathrm{Mg}$ per hectare). The explanation therefore remains a 
hypothesis that requires testing against other cases. There are a few cases that hint towards significantly reduced penetration when the organic matter levels has increased after a first amendment year (He, Endale, Schomberg, \& Jenkins, 2009, No till case; Schroder, 2010, cases 180, 269, and $539 \mathrm{~kg} \mathrm{~N}$ per hectare; Sukkariyah, Evanylo, \& Zelazny, 2007, Acredale case; McGrath \& Lane, 1989; Asada, Yabushita, Saito, \& Nishimura, 2011). However, due to lack of data on i.a. organic matter levels, it has not been possible to quantify any reduced penetration rate.

\subsection{Penetration of Metals below the Topsoil and Losses to Sinks}

The loss of metal from the topsoil raises the issue of loss to groundwater after passage of deeper subsoil layers. The lost metal would mainly proceed to the groundwater if there were no accumulation in the soil on the way to the groundwater. Two modes of accumulation were analysed: fixation in the subsoil and losses to sinks for metals.

\subsubsection{Fixation in the Subsoil}

Accumulation in the subsoil at 1 to 2 meters depth seems rather uncommon. Out of 13 cases reporting measurements at these depths, only one suggested any strong accumulation:

$>$ The copper concentrations of 5 locations were lower at $100 \mathrm{~cm}$ depth than at $50 \mathrm{~cm}$ depth (Benö, Facchinelli, Franchini Angela, \& Fornelli Genot, 2009, cases A-ELO4/1, A-ELO5/1, VA3, VA4, 38-110 years old vineyards. max depth $150 \mathrm{~cm}$; Fan, He, Ma, \& Stoffella, 2011, case 12, 23 year old vineyard, max depth 120 $\mathrm{cm})$.

$>$ The concentrations of cadmium, copper and zinc of 2 locations were lower at $100 \mathrm{~cm}$ depth than at $50 \mathrm{~cm}$ depth (Flores-Delgadillo, Hernandez-Silva, Alcala-Martinez, \& Maples-Vermeersch, 1992, cases 62 and 63, soils irrigated with wastewater for more than 40 years, max depth $170 \mathrm{~cm}$, organic matter and $\mathrm{pH}$ levels similar at 50 $\mathrm{cm}$ and $100 \mathrm{~cm}$ ).

$>$ In one location, Zabiele, the concentrations of 6 measured metals were much lower at $100 \mathrm{~cm}$ depth than at $50 \mathrm{~cm}$ depth, while in another, Bogomice, the concentrations increased strongly below $100 \mathrm{~cm}$. This increase was in proportion to the organic matter increase associated with at layer of clay and silt appearing below $100 \mathrm{~cm}$ depth in the otherwise very sandy soil (Kabala \& Singh, 2001, fallout from smelters established 40 years ago, max depth $120 \mathrm{~cm}$ ).

$>$ The concentrations of cadmium, copper, lead and zinc in one location were lower at $100 \mathrm{~cm}$ depth than at $50 \mathrm{~cm}$ depth; however there was a local increase with depth around $1 \mathrm{~m}$ depth for cadmium, copper and zinc suggesting locally changed soil parameters (Labanowski et al., 2008, fallout from smelter operated 30-100 years ago, max depth $125 \mathrm{~cm}$ ).

$>$ Concentrations of copper and zinc were the same or lower at $100 \mathrm{~cm}$ depth than at $50 \mathrm{~cm}$ depth at 2 locations. Organic matter decreased somewhat with depth while $\mathrm{pH}$ was constant or increasing (Mbila, Thompson, Mbagwu, \& Laird, 2001, sewage sludge deposition sites since 37 years, total $1665 \mathrm{Mg} / \mathrm{ha}$, max depth $160 \mathrm{~cm})$.

> The concentrations of copper and zinc in one location were nearly the same at $100 \mathrm{~cm}$ depth as at $50 \mathrm{~cm}$ depth while organic matter was constant and $\mathrm{pH}$ increased with depth (Richards, Steenhuis, Peverly, \& McBride, 1998, massive sewage sludge amendment 17 years ago).

Thus, even for century-old contamination, metal concentrations decreased with depth as long as there were no abrupt changes with depth of important soil parameters. Nor does a regional model for metal transport envisage such accumulation (Römkens, Bonten, \& Rietra, 2004). The model for concentration in soil solution contains essentially the parameters of the penetration equation in similar structure. Additionally it uses the concentrations of dissolved organic carbon and of oxalate extractable iron and aluminium. However, the model does not treat deeper losses more generally.

\subsubsection{Losses to Established Sinks}

Even though many metals largely find their way through the subsoil to groundwater, there are examples when the metals may be trapped for long times in sinks.

Peat is a very efficient sink for silver and copper. Peat soil was the only case involving an important sink that was mentioned by Groenenberg, Römkens and de Fries (2006) in analyses of regional metal transport. In such soil, the groundwater concentration reflected the water that had leaked from the soil with a significant loss, reaching only about one-tenth of the level expected without sinks. 
$>$ In natural marshland, the removal can be $20-30 \%$ for copper and silver (Rozan \& Benoit, 2001). Significant removal was seen in an engineered wetland for waste water for several metals but not for arsenic and nickel (Dombeck, Perry, \& Phinney, 1998). It is however not clear how lasting this removal is since sediment resuspension may be a very important mechanism for releasing silver and copper into the water column (Kalnejais, Martin, Signell, \& Bothner, 2007).

An important mechanism for removal is binding to sulfides (International Council on Metals \& Mining, 2007). The sulfides available for binding are known to become depleted at high loadings, reducing the sink capacity.

$>$ These data taken together indicate that without engineered sinks there may be some removal of silver and copper after the metals have passed the topsoil, but a large part of the metal can be expected to make its way through to the groundwater. Over a century or more, it is hard to justify any major general reduction of environmental concentrations due to silver or copper being trapped in sinks, except for the trapping in peat.

\subsubsection{Protection against Enhanced Levels of Naturally Occurring Substances}

Background levels usually have a broad distribution around a mean. The EU guidance on metal risk assessment (European Chemicals Agency, 2008) does not give a clear guidance on the point of departure within this distribution. Some examples of interpretations with respect to the distribution are the following:

> The Swedish Environment Agency has issued guidance for deriving environmental quality standards for contaminated sites (Naturvårdsverket, 2009). In the model, if a quality standard is derived that is lower than the natural background, the standard is raised to the $90^{\text {th }}$ percentile of the natural background level.

$>\quad$ The Geological Survey of Sweden (2013) has issued reference values for groundwater indicating a status that does not deviate or only insignificantly deviates from undisturbed conditions. The concentration is $5-23$ times the median natural concentration. The reference levels have been one of the inputs in the derivation of environmental quality standards. Predicted No Effect Concentrations (PNEC) have been used by the Swedish Environmental Protection Agency (Naturvårdsverket, 2013) in discussions of permissible loads of sludge to Swedish farmlands. Their data are from Sternbeck, Österås, and Allmyr (2013). The PNEC values for copper and cadmium are near the mentioned reference levels, while those for lead, chromium and nickel are several times above the reference levels. Thus no environmental effects should be expected in cases of compliance with the reference levels. The Austrian environmental quality standard 461 (Bundesministerium für Land- und Forstwirtschaft, Umwelt und Wasserwirtschaft, 2010) for silver is $0.1 \mathrm{ug} / \mathrm{l}$, which is 17 times freshwater silver levels, in line with the relation PNEC/background for the other mentioned metals.

> Further, EU-wide environmental quality standards have been established at considerably higher levels (80-400 times median natural levels) for cadmium, lead and arsenic. The environmental quality standards are identical to those of a Swedish regulation for public drinking water (National Food Agency, 2013).

$>$ The Austrian regulation on quality standards for groundwater 98 (Bundesministerium für Land- und Forstwirtschaft, Umwelt und Wasserwirtschaft, 2010) states that the groundwater status in a monitored site should not be considered hazardous if exceedance of the standard is based on a geogenic or other natural background value. In a remark (Erläuternde Bemerkungen, Bundesministerium für Land- und Forstwirtschaft, Umwelt und Wasserwirtschaft, 2010) the geogenic background value is defined as the highest measured or expected value due to geology.

$>$ A guidance document to the EU Water Framework Directive (European Union, 2009) discussed actions regarding groundwater bodies. In the document it is argued that an intermediate between the levels in the three previous bullets $\left(90^{\text {th }}\right.$ percentile and highest) is to be preferred: "Given the fact that the 90 percentile will often be chosen as a criterion for the selection of background level at least $10 \%$ of the observation wells are expected to show exceedances if the threshold value is set exactly at the background level concentration. This would inevitably lead to an 'appropriate investigation' for all groundwater bodies under case 2, which is considered unworkable."

\section{References}

Allison, J. D., \& Allison, T. L. (2005). Partition coefficients for metals in surface water, soil and waste. Report EPA/600/R-05/074 US Environmental Protection Agency, Washington DC 20460. Retrieved from http://www.researchgate.net/publication/237633308_Partition_Coefficients_for_Metals_in_Surface_Water_ Soil_and_Waste_EPA600R-05074

Alloway, B. J. (Ed.). (2013). Heavy Metals in Soils. Trace Metals and Metalloids in Soils and their 
Bioavailability. Berlin, Germany: Springer Science+Business Media B.V. Retrieved from http://www.springer.com/us/book/9789400744691

Altaher, H. M. (2001). Factors affecting mobility of copper in soil-water matrices (Dissertation, The Virginia Polytechnic Institute and State University, Blacksburg, Virginia). Retrieved from http://www.researchgate.net/publication/255649480_FACTORS_AFFECTING_MOBILITY_OF_COPPER _IN_SOIL-WATER_MATRICES

Andrén, O., Kätterer, T., Karlsson, T., \& Eriksson, J. (2008). Soil C balances in Swedish agricultural soils 1990-2004, with preliminary projections. Nutrient Cycling in Agroecosystems, 81, 129-144. http://dx.doi.org/10.1007/s10705-008-9177-z

Arthur, E., Moldrup, P., Holmstrup, M., Schjønning, P., Winding, A., Mayer, D., \& de Jonge, L. W. (2012). Soil microbial and physical properties and their relations along a steep copper gradient. Agriculture Ecosystems Environment, 158, 9-18. http://dx.doi.org/10.1016/j.agee.2012.06.021

Asada, K., Yabushita, Y., Saito, H., \& Nishimura, T. (2011). Effect of long-term swine-manure application on soil hydraulic properties and heavy metal behavior. European Journal of Soil Science, 63, 368-376. http://dx.doi.org/10.1111/j.1365-2389.2012.01437.x

Azevedo Silveira, M. L., Ferracciú Alleoni, L. R., \& Guimarães Guilherme, L. R. (2003). Biosolids and heavy metals in soils. Scientia Agricola, 60, 793-806. Retrieved from http://www.scielo.br/scielo.php?script=sci_arttext\&pid=S0103-90162003000400029

Barajas-Aceves, M. (2005). Comparison of different microbial biomass and activity measurement methods in metal-contaminated Soils. Bioresource Technology, $1405-1414$. http://dx.doi.org/10.1016/j.biortech.2004.09.013

Barreto, A. N., do Nascimento, J. J. V. R., de Medeiros, E. P., da Nóbrega, J. A., \& Bezerra, J. R. C. (2013) Changes in chemical attributes of a Fluvent cultivated with castor bean and irrigated with wastewater. Revista Brasileira de Engenharia Agrícola e Ambiental, 17, 480-486. http://dx.doi.org/10.1590/S1415-43662013000500003

Baveye, P., McBride, M. B., Bouldin, D., Hinesly, T. D., Dahdoh, M. S. A., \& Abdel-Sabour, M. F. (1999). Mass balance and distribution of sludge-borne trace elements in a silt loam soil following long-term applications of sewage sludge. The Science of the Total Environment, 227, 13-28. http://www.ingentaconnect.com/content/els/00489697/1999/00000227/00000001/art00396

Benő, E., Facchinelli, A., Franchini Angela, M., \& Fornelli Genot, S. (2009). Copper pollution in some vineyard soils of the Piedmont region (Italy): Accumulation and mobility. International Journal of Environment and Waste Management, 3. http://dx.doi.org/10.1504/IJEWM.2009.026350

Bespalova, A. Y., Motuzova, G. V., \& Marfenina, O. E. (2002). Secondary mobilization of heavy metals in polluted soils under microbial influence (model experiment). Developments in Soil Science, 28, 187-193. http://dx.doi.org/10.1016/S0166-2481(02)80016-2

Bețianu, C., Brînză, L., Pavel, V., \& Gavrilescu, M. (2007). Partition and sorption of heavy metals to soils. Universitatea de Ştiințe Agricole şi Medicină Veterinară Iaşi. 50 Seria Agronomie, 340-345. Retrieved from http://www.revagrois.ro/PDF/2007_340.pdf

Bin, G., Cao, X., Dong, Y., Luo, Y., \& Ma, L. (2011). Colloid deposition and release in soils and their association with heavy metals. Critical Reviews in Environmental Science and Technology, 41, 336-372. http://dx.doi.org/10.1080/10643380902871464

Bonten, L. T. C., \& Groenenberg, J. E. (2008). Leaching of heavy metals from farmland and uncultivated land. Version dated May 2008. Wageningen, The Netherlands: Alterra. Retrieved from http://www.emissieregistratie.nl/erpubliek/documenten/Water/Factsheets/English/Heavy\%20metals\%20fro $\mathrm{m} \% 20$ farmland.pdf

Bradford, S. A., \& Torkzaban, S. (2007). Colloid transport and retent on in unsaturated porous media: a review of interface-, collector-, and pore-scale processes and models. Vadose Zone Journal, 7, 667-681. http://dx.doi.org/10.2136/vzj2007.0092

Bundesministerium für Land- und Forstwirtschaft, Umwelt und Wasserwirtschaft. (2010). Qualitätszielverordnung Chemie Grundwsser. Vienna, Austria: Bundesministerium für Land- und Forstwirtschaft, Umwelt und Wasserwirtschaft. Retrieved from http://www.bmlfuw.gv.at/wasser/wasser-oes 
terreich/wasserrecht_national/planung/QZVChemieGW.html

Burton, E.D., Phillips, I. R., Hawker, D. W., \& Lamb, D. T. (2005). Copper behaviour in a Podosol 1 $\mathrm{pH}$-dependent sorption-desorption, sorption isotherm analysis, and aqueous speciation modeling. Australian Journal of Soil Research, 43, 491-501. http://dx.doi.org/10.1071/SR04117

Chaudhari, P. R., Ahire, D. V., Ahire, V. D., Chkravarty, M., \& Maity, S. (2013) Soil bulk density as related to soil texture. organic matter content and available total nutrients of Coimbatore soil. International Journal of Scientific and Research Publications, 3, 1-8. http://dx.doi.org/10.15373/22778179/MARCH2014/162

Chaudri, A. M., McGrath, S. P., Giller, K. E., Rietz, E., \& Sauerbeck, D. R. (1993). Enumeration of indigenous Rhizobium Leguminosarum biovar Trifolii in soils previously treated with metal-contaminated sewage sludge. Soil Biology and Biochemistry, 25, 301-309. http://dx.doi.org/10.1016/0038-0717(93)90128-X

Chino, M., Goto, S., Kumazawa, K., Owa, N., Yoshioka, O., Takechi, N., ... Youssef, R. A. (1992) Behaviour of zinc and copper in soil with long term application of sewage sludges. Soil Science and Plant Nutrition, 1, 159-167. http://dx.doi.org/10.1080/00380768.1992.10416963

Czarnecki, S., \& Düring, R. A. (2015). Influence of long-term mineral fertilization on metal contents and properties of soil samples taken from different locations in Hesse, Germany. Soil, 1, 23-33. http://dx.doi.org/10.5194/soil-1-23-2015

De Boer, T. E., Tas, N., Braster, M., Temminghoff, E. J. M., Röling, W. F. M., \& Roelofs, D. (2012). The influence of long-term copper contaminated agricultural soil at different $\mathrm{pH}$ levels on microbial communities and springtail transcriptional regulation. Environmental Science and Technology, 46, 60-68. http://dx.doi.org/10.1021/es2013598

Deb, S. K., \& Shukla, M. K. (2011). A review of dissolved organic matter transport processes affecting soil and environmental quality. Journal of Environmental Analytical Toxicology, 1, 106. http://dx.doi.org/10.4172/2161-0525.1000106

DEFRA. (2007). Effects of sewage sludge applications to agricultural soils on soil microbial activity and the implications for agricultural productivity and long-term soil fertility: Phase III Report Ref (SP0130; CSA 222). Retrieved from http://randd.defra.gov.uk/Default.aspx?Module=More\&Location=None\&ProjectID=1 0677

Dombeck, G. D., Perry, M. W., \& Phinney, J. (1998). Mass balance on water column trace metals in a free-surface-flow-constructed wetlands in Sacramento, California. Ecological Engineering, 10, 313-339. http://dx.doi.org/10.1016/S0925-8574(98)00045-7

Dowdy, R. H., Latterell, J. J., Hinesly, T. D., Grossman, R. B., \& Sullivan, D. L. (1991). Trace Metal Movement in an Aeric Ochraqualf following 14 Years of Annual Sludge Applications. Journal of Environmental Quality, 20, 119-123. Retrieved from http://www.researchgate.net/publication/238447839_Trace_Metal_M ovement_in_an_Aeric_Ochraqualf_following_14_Years_of_Annual_Sludge_Applications

Eijsackers, H., Benekec, P., Maboetac, M., Louwd, J. P. E., \& Reinecke, A. J. (2005). The implications of copper fungicide usage in vineyards for earthworm activity and resulting sustainable soil quality. Ecotoxicology and Environmental Safety, 62, 99-111. http://dx.doi.org/10.1016/j.ecoenv.2005.02.017

Ejhed, H., Liljeberg, M., Olshammar, M., Wallin, M., Rönnback, P., \& Stenström, A. (2010). Bruttobelastning på vatten av metaller från punktkällor och diffusa källor - Slutrapport. SMED Rapport Nr 41 2010. SMED Norrköping, Sweden: SMHI. Retrieved from http://www.smed.se/wp-content/uploads/2011/05/SMED_Rap port_2010_41.pdf

European Union. (2009). Common implementation strategy for the water framework directive (2000/60/ec). Guidance Document No 18.3333 Guidance on groundwater status and trend assessment Luxembourg: Office for Official Publications of the European Communities. Retrieved from http://bookshop.europa.eu/en/guidance-on-groundwater-status-and-trend-assessment-pbKHAN09018

European Union. (2011). Assessment report Copper (II) oxide. Retrieved from http://dissemination.echa.europa.eu/Biocides/ActiveSubstances/0017-08/0017-08_Assessment_Report.pdf

Fairbrother, A., \& McLaughlin, M. J. (2002). Metalloregions. Fact sheet on environmental risk assessment No 12. Published by the International Council on Mining and Metals (ICMM). Retrieved from http://www.icmm.com/document/46

Fan, J., He, Z., Ma, L. Q., \& Stoffella, P. J. (2011). Accumulation and availability of copper in citrus grove soils 
as affected by fungicide application. Journal of Soils and Sediments, 11, 639-648. http://dx.doi.org/10.1007/s11368-011-0349-0

Flores-Delgadillo, L., Hernandez-Silva, G., Alcala-Martinez, R., \& Maples-Vermeersch, M. (1992). Total contents of cadmium, copper, manganese and zinc in agricultural soils irrigated with wastewater from Hidalgo, Mexico. Revista Internacional de Contaminación Ambiental, 8, 37-46. Retrieved from http://www.oalib.com/paper/2553273\#.VffWo1vos5s

Geological Survey of Sweden. (2013). Sveriges geologiska undersöknings föreskrifter om miljökvalitetsnormer och statusklassificering för grundvatten. Uppsala, Sweden: Sveriges Geologiska Undersökning. Retrieved from http://resource.sgu.se/dokument/om-sgu/foreskrifter/sgu-fs-2013-2.pdf

Girotto, E., Ceretta, C. A., Brunetto, G., Rheinheimer dos Santos, D., Souza da Silva, L., Rogério Lourenzi, C., ... Schmatz, R. (2010). Acúmulo e formas de cobre e zinco no solo após aplicações sucessivas de dejeto líquido de suínos. Revista Brasileira de Ciencias do Solo, 34, 955-965. http://dx.doi.org/10.1590/S0100-06832010000300037

Guardini, R., Comin, J. J., Rheinheimer dos Santos, D., Colpo Gatiboni, L., Tiecher, T., ... Gustavo, B. (2012). Phosphorus accumulation and pollution potential in a Hapludult fertilized with pig manure. Revista Brasileira de Ciência do Solo, 36, 1333-1342. http://dx.doi.org/10.1590/S0100-06832012000400027

Hemmat, A., Aghilinategh, N., Rezainejad, Y., \& Sadeghi, M. (2010). Long-term impacts of municipal solid waste compost. sewage sludge and farmyard manure application on organic carbon. bulk density and consistency limits of a calcareous soil in central Iran. Soil and Tillage Research, 108, 43-50. http://dx.doi.org/10.1016/j.still.2010.03.007

International Council on Metals \& Mining. (2007). MERAG Metals Environmental Risk Assessment Guidance. London, United Kingdom: International Council on Metals \& Mining. Retrieved from http://www.icmm.com/document/15

Iovieno, P., \& Bååth, E. (2008). Effect of drying and rewetting on bacterial growth rates in soil. FEMS Microbiology Ecology, 65, 400-407. http://dx.doi.org/10.1111/j.1574-6941.2008.00524.x

Ippolito, J. A., Barbarick, K. A., \& Brobst, R. B. (2009). Fate of biosolids $\mathrm{Cu}$ and $\mathrm{Zn}$ in a semi-arid grassland. Agriculture, Ecosystems and Environment, 131, 325-332. http://dx.doi.org/10.1016/j.agee.2009.02.013

Ippolito, J. A., Ducey, T. F., \& Tarkalson, D. D. (2011). Interactive effects of copper on alfalfa growth, soil copper, and soil bacteria. Journal of Agricultural Science, 3, 138-148. http://dx.doi.org/10.5539/jas.v3n2p138

Jacobson, A. R., Dousset, S., Andreux, F., \& Baveye, P. C. (2007). Electron microprobe and synchrotron x-ray fluorescence mapping of the heterogeneous distribution of copper in high-copper vineyard soils. Environmental Science \& Technology, 41, 6343-9. http://dx.doi.org/10.1021/es070707m

Jacques, D., Simunek, J., Mallants, D., \& van Genuchten, M. Th. (2008). Modelling coupled water flow. solute transport and geochemical reactions affecting heavy metal migration in a podzol soil. Geoderma, 145, 449-461. http://dx.doi.org/10.1016/j.geoderma.2008.01.009

Kabala, C., \& Singh, B. R. (2001). Fractionation and mobility of copper, lead, and zinc in soil profiles in the vicinity of a copper smelter. Journal of Environmental Quality, 30, 485-492. Retrieved from http://karnet.up.wroc.pl/ kabala/jeq-30-2-485.pdf

Kalnejais, L. H., Martin, W. R., Signell, R. P., \& Bothner, M. H. (2007). Role of sediment resuspension in the remobilization of particulate-phase metals from coastal sediments. Environmental Science Technology 41, 2282-2288. http://dx.doi.org/10.1021/es061770z

Karathanasis, A. D., \& Johnson, D. M. C. (2006). Stability and transportability of biosolid colloids through undisturbed soil monoliths. Geoderma, 130, 334-345. http://dx.doi.org/10.1016/j.geoderma.2005.02.006

Kilic, S., Agca, N., \& Yalcin, M. (2004). Soils of Amik plain (Turkey): Properties and classification. Journal of Agronomy, 3, 291-295. http://dx.doi.org/10.3923/ja.2004.291.295

Kretzschmar, R., \& Schäfer, T. (2005) Metal retention and transport on colloidal particles in the environment. Elements, 1, 205-210. http://dx.doi.org/10.2113/gselements.1.4.205

Kwon, S.-I., Jang, Y.-A., Owens, G., Kim, M.-K., Jung, G.-B., Hong, S.-C., ... Kim, K. R. (2013). Long-term assessment of the environmental fate of heavy metals in agricultural soil after cessation of organic waste treatments. 
http://dx.doi.org/10.1007/s10653-013-9569-0

Lamy, I. (2006). Les Interactions Matières Organiques du Sol - Eléments Traces Métalliques: Enjeux Scientifiques et Environnementaux (Dissertation for habilitation, University of Poitiers, Poitiers, France). Retrieved from http:/www-pessac.versailles.inra.fr/documentation/travaux/HDR-LAMY.pdf

Lottermoser, B. G. (2012). Effect of long-term irrigation with sewage effluent on the metal content of soils, Berlin, Germany. Environmental Geochemistry and Health, 34, 67-76. http://dx.doi.org/101007/s10653-011-9391-5

Lu, Q., He, Z., \& Stoffella, P. J. (2012). Land Application of Biosolids in the USA: A Review. Applied and Environmental Soil Science, 2012, 11. http://dx.doi.org/10.1155/2012/201462

Ma, Y., Lombi, E., Oliver, I. W., Nolan, A. L., \& McLaughlin, M. J. (2006). Long-term aging of copper added to soils. Environmental Science \& Technology, 40, 6310-6317. http://dx.doi.org/10.1021/es060306r

Mantovi, P., Baldoni, G., Dal Re, L., Piccinini, S., \& Rossi, L. (2006). Effects of 15 years sludge application on cropland. Water Practice \& Technology. http://dx.doi.org/10.2166/wpt.2007.015

Mbila, M. O., Thompson, M. L., Mbagwu, J. S. C., \& Laird, D. A. (2001). Distribution and movement of sludge-derived trace metals in selected Nigerian soils. Journal of Environmental Quality, 30, 1667-1674. http://dx.doi.org/10.2134/jeq2001.3051667x

McGrath, S. P., \& Lane, P. W. (1989). An explanation for the apparent losses of metals in a long-term field experiment with sewage sludge. Environmental Pollution, 60, 235-56. http://dx.doi.org/10.1016/0269-7491(89)90107-3

McLaughlin, M.-J., Lofts, S., Warne, M. St. J., Amorim, M. J. B., Fairbrother, A., Lanno, R., ... Paton, G. I. (2010). Derivation of ecologically based soil standards for trace elements. In G. Merrington \& I. Schoeters (Eds.), Soil quality standards for trace elements: derivation. implementation. and interpretation. London: CRC Press, Taylor and Francis Group.

Menzi, H., \& Kessler, J. (1998). Heavy metal content of manures in Switzerland. Retrieved from http://www.ramiran.net/doc98/FIN-ORAL/MENZI.pdf

Michalk, D. L., Curtis, I. H., Seaman, J., Langford, C. M., \& Osborne, G. J. (1995). Evaluation of sewage sludge products for use in sheep production in Australia: Some preliminary results. Proceedings of a seminar 1995 on effects of land application of biosolids in the arid and semi-arid west. USEPA National Service Center for Environmental Publications (NSCEP). Retrieved from http://grasslandnsw.com.au/news/wp-content/upl oads/2011/09/Michalk-Bamforth-Hird-Simpson-Langford-Osborne-1994.pdf

Natal-da-Luz, T., Ojeda, G., Costa, M., Pratas, J., Lanno, R. P., Van Gestel, C. A. M., \& Sousa, J. P. (2012). Short-term changes of metal availability in soil part i: Comparing sludge-amended with metal-spiked soils. Archives of Environmental Contamination and Toxicology, 63, 199-208. http://dx.doi.org/10.1007/s00244-012-9763-6

National Food Agency. (2013). Livsmedelsverkets föreskrifter om dricksvatten. Uppsala, Sweden: Livsmedelsverket. Retrieved from http://www.livsmedelsverket.se/om-oss/lagstiftning1/gallande-lagstiftnin g/slvfs-200130

Naturvårdsverket. (2009). Riktvärden för förorenad mark. Modellbeskrivning och vägledning. Rapport 5976. Stockholm, Sweden: Naturvårdsverket. Retrieved from http:/www.naturvardsverket.se/Documents/publika tioner/978-91-620-5976-7.pdf?pid=3574

Naturvårdsverket. (2013). Hållbar återföring av fosfor. Naturvårdsverkets redovisning av ett uppdrag från regeringen. Rapport 6580. Stockholm, Sweden: Naturvårdsverket. Retrieved from http:/www.naturvardsverket.se/Documents/publikationer6400/978-91-620-6580-5.pdf

North Central Regional Research. (1998). Recommended chemical soil test procedures for the North Central Region Publication No 221 (Revised 2012). Missouri Agricultural Experiment Station SB 1001. Retrieved from http://extension.missouri.edu/publications/DisplayPub.aspx?P=SB1001

Oorts, K. (2013). Heavy Metals in Soils, Chapter 13. Copper. In B. J. Alloway (Ed.), Environmental Pollution (Vol. 22, pp. 367-394). Retrieved from http://link.springer.com/book/10.1007\%2F978-94-007-4470-7

Packer, I. J., Medway, J., Jones, B., \& Koen, T. (1998). Are 'conservative’ cropping systems improving soil infiltration, organic carbon and bulk density in southern NSW? 9th Australian Agronomy Conference. Australian Society of Agronomy. Retrieved from http://www.regional.org.au/au/asa/1998/8/157packer.htm 
Percival, H. J. (2003). Soil and soil solution chemistry of a New Zealand pasture soil amended with heavy metal-containing sewage sludge. Australian Journal of Soil Research, 41, 1-17. http://dx.doi.org/10.1071/SR01061

Richards, B. K., Steenhuis, T. S., Peverly, J. H., \& McBride, M. B. (1998). Metal mobility at an old. heavily loaded sludge application site. Environmental Pollution, 99, 365-377. http://dx.doi.org/10.1016/S0269-7491(98)00011-6

Ritter, L., Solomon, K., Sibley, P., Hall, K., Keen, P., Mattu, G., \& Linton, B. (2002). Sources, pathways, and relative risks of contaminants in surface water and groundwater: a perspective prepared for the Walkerton inquiry. Journal of Toxicology and Environmental Health, Part A, 65, 1-142. http://dx.doi.org/10.1080/152873902753338572

Rosén, K., Öborn, I., \& Lönsjö, H. (1999). Migration of radiocaesium in Swedish soil profiles after the Chernobyl accident, 1987-1995. Journal of Environmental Radioactivity, 46, 45-66. http://dx.doi.org/10.1016/S0265-931X(99)00040-5

Roudsary, O. N., \& Pishdar, H. (2007). Evaluation of composted sewage sludge (css) as a soil amendment for bermudagrass growth. Pakistan Journal of Biological Sciences, 10, 1371-1379. http://dx.doi.org/10.3923/pjbs.2007.1371.1379

Rozan, T. F., \& Benoit, G. (2001). Mass balance of heavy metals in New Haven Harbor, Connecticut: Predominance of nonpoint sources. Limnology and Oceanography, 46, 2032-2049. http://dx.doi.org/10.4319/lo.2001.46.8.2032

Rumpel, C., \& Kögel-Knabner, I. (2011). Deep soil organic matter - A key but poorly understood component of terrestrial C cycle. Plant Soil, 338, 143-158. http://dx.doi.org/10 1007/s11104-010-0391-5

Salehi, M. H., Hashemi Beni, O., Beigi Harchegani, H., Esfandiarpour Borujeni, I., \& Motaghian, H. R. (2011). Refining soil organic matter determination by loss-on-ignition. Pedosphere, 21, 473-482. http://dx.doi.org/10.1016/S1002-0160(11)60149-5

Schroder, J. L., Zhang, H., Zhou, D., Basta, N., Raun, W. R., Payton, M. E., \& Zazulak, A. (2008). The effect of long-term annual application of biosolids on soil properties. phosphorus. and metals. Soil Science Society of America Journal, 72, 73-82. http://dx.doi.org/10.2136/sssaj2007.0025

Settimio, L., McLaughlin, M. J., Kirby, J. K., Langdon, K. A., Lombic, E., Donner, E., \& Scheckeld, K. G. (2014). Fate and lability of silver in soils: Effect of ageing. Environmental Pollution, 191, 151-157. http://dx.doi.org/10.1016/j.envpol.2014.04.030

Shang, Z., \& Leung, J. K. C. (2003). A study of $110 \mathrm{mAg}$ in aquatic and terrestrial ecosystems. Radiation and Environmental Biophysics, 42, 33-40. http://dx.doi.org/10.1007/s00411-003-0178-7

Shotyk, W., Krachler, M., Aeschbach-Hertig, W., Hillier, S., \& Zheng, J. (2010). Trace elements in recent groundwater of an artesian flow system and comparison with snow: enrichments. depletions. and chemical evolution of the water. Journal of Environmental Monitoring, 12, 208-217. http://dx.doi.org/10.1039/B909723F

Sizmur, T., \& Hodson, M. E. (2009). Do earthworms impact metal mobility and availability in soil? - A review. Environmental Pollutio, 157, 1981-1989. http://dx.doi.org/ 10 1016/j envpol 200902029

Smith, S. (2009). A critical review of the bioavailability and impacts of heavy metals in municipal solid waste composts compared to sewage sludge. Environment International, 35, 142-156. http://dx.doi.org/10.1016/j.envint.2008.06.009

Smolders, E., Oorts, K., Lombi, E., Schoeters, I., Ma, Y., Zrna, S., \& McLaughlin, M. J. (2012). The availability of copper in soils historically amended with sewage sludge. manure. and compost. Journal of Environmental Quality, 41, 506-514. http://dx.doi.org/10.2134/jeq2011.0317

Sojka, R. E., Busscher, W. J., \& Lehrsch, G. A. (2001). In situ strength, bulk density, and water content relationships of a Durinodic Xeric Haplocalcid soil. Soil Science, 166, 520-529. http://dx.doi.org/10.1097/00010694-200108000-00003

Sternbeck, J., Österås, A. H., \& Allmyr, M. (2013). Riskbedömning av fosforrika fraktioner vid återförsel till åker- och skogsmark samt vid anläggande av etableringsskikt. Stockholm: WSP Environmental. Retrieved from http://www.naturvardsverket.se/upload/miljoarbete-i-samhallet/miljoarbete-i-sverige/regeringsuppdra g/2013/fosfor/underlagsrapporter/riskbedomning-fosforrika-fraktioner-aterforsel-2013.pdf 
Stöven, K., Al-Assa, A., Rogasik, J., Krdatz, S., \& Schnug, E. (2005). Effect of long term sewage sludge applications on micro-organisms in an arable soil. Landbauforschung Völkenrode, 4, 219-226. Retrieved from http://literatur.ti.bund.de/digbib_extern/bitv/zi038682.pdf

Sukkariyah, B. F., Evanylo, G., \& Zelazny, L. (2007). Distribution of copper, zinc, and phosphorus in coastal plain soils receiving repeated liquid biosolids applications. Journal of Environmental Quality, 36, 1618-1626. http://dx.doi.org/10.2134/jeq2006.0558

Sukkariyah, B. F., Evanylo, G., Zelazny, L., \& Chaney, R. L. (2005). Recovery and distribution of biosolids-derived trace metals in a clay loam soil. Journal of Environmental Quality, 34, 1843-1850. http://dx.doi.org/10.2134/jeq2004.0180

Torri, S. I., \& Corréa, R. S. (2012). Downward movement of potentially toxic elements in biosolids amended soils. Applied and Environmental Soil Science, Article ID 145724. http://dx.doi.org/101155/2012/145724

USDA-NRCS. (September 14, 2015). Soil organic matter Soil quality kit - Guide for educators. Retrieved from http://www.nrcs.usda.gov/Internet/FSE_DOCUMENTS/nrcs142p2_053264.pdf

Usmani, Z., \& Kumar, V. (2015). Role of earthworms against metal contamination: A review. Journal of Biodiversity and Environmental Sciences, 6, 414-427. Retrieved from http://www.innspub.net/wp-content/uploads/2015/01/JBES-Vol6No1-p414-427.pdf

Van Zwieten, L., Rusta, J., Kingston, T., Merrington, G., \& Morris, S. (2004). Influence of copper fungicide residues on occurrence of earthworms in avocado orchard soils. Science of the Total Environment, 329, 29-41. http://dx.doi.org/10.1016/j.scitotenv.2004.02.014

Violante, A., Cozzolino1, V., Perelomov, L., Caporale, A. G., \& Pigna, M. (2010). Mobility and bioavailability of heavy metals and metalloids in soil environments. Journal of Soil Science and Plant Nutrition, 10, 268-292. http://dx.doi.org/10.4067/s0718-95162010000100005

Weber, F.-A., Voegelin, A., Kaegi, R., \& Kretzschmar, R. (2009). Contaminant mobilization by metallic copper and metal sulphide colloids in flooded soil. Nature Geoscience Journal, 2, 267-271. http://dx.doi.org/10.1038/NGEO476

Wu, J., Laird, D. A., \& Thompson, M. L. (1999). Sorption and desorption of copper on soil clay components. $\begin{array}{lllll}\text { Journal of } & \text { Environmental } & \text { Quality, } & \text { 334-338. }\end{array}$ http://dx.doi.org/10.2134/jeq1999.00472425002800010041x

Xiong, X., Li, Y., Li, W., Lin, C., Han, W., \& Yang, M. (2010). Copper content in animal manures and potential risk of soil copper pollution with animal manure use in agriculture. Resources Conservation and Recycling, 54, 985-990. http://dx.doi.org/10.1016/j.resconrec.2010.02.005

Yingming, L., \& Corey, R. B. (1993). Redistribution of sludge-borne cadmium, copper, and zinc in a cultivated $\begin{array}{lllll}\text { plot. Journal of } & \text { Euality, } & 22, & 1-8 .\end{array}$ http://dx.doi.org/10.2134/jeq1993.00472425002200010001x

\section{Copyrights}

Copyright for this article is retained by the author(s), with first publication rights granted to the journal.

This is an open-access article distributed under the terms and conditions of the Creative Commons Attribution license (http://creativecommons.org/licenses/by/3.0/). 